\begin{tabular}{|c|c|c|c|c|c|}
\hline \multirow{3}{*}{$\begin{array}{l}\text { 2. ECN Category } \\
\text { (mark one) } \\
\text { Supplemental } t] \\
\text { Direct Revision } \\
\text { Change ECN } \\
\text { Temporary } \\
\text { Standby } \\
\text { Supersedure } \\
\text { Cancel/Noid }\end{array}$} & \multirow{3}{*}{ 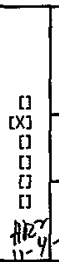 } & \multicolumn{2}{|c|}{$\begin{array}{l}\text { 3. Originator's Name, Organization, MSIN, } \\
\text { and Telephone No. } \\
\text { H.R. Risenmay, PFP Process } \\
\text { Engineering, T5-55, } 373-3503\end{array}$} & $\begin{array}{l}\text { 4. USQ Required? } \\
{[X] \text { Yes [] No }}\end{array}$ & $\begin{array}{l}\text { 5. Date } \\
\text { OCTOBER 27, } 1998\end{array}$ \\
\hline & & \multicolumn{2}{|c|}{$\begin{array}{l}\text { 6. Project Title/No./Work order No. } \\
\text { Thermal Stabilization }\end{array}$} & $\begin{array}{l}\text { 7. Bldg./Sys./Fac. No. } \\
\text { PFP/73T/234-5Z }\end{array}$ & $\begin{array}{l}\text { 8. Approval Designat } \\
\text { Q, S, (R) }\end{array}$ \\
\hline & & \multicolumn{2}{|c|}{$\begin{array}{l}\text { 9. Document Numbers Changed by this ECN } \\
\text { (ingledes sheet no. and rev.) } \\
96 \text { HeV-SD-CP-SDD-017, Rev. } 2\end{array}$} & $\begin{array}{l}\text { 10. Related ECN No(s). } \\
\text { N/A }\end{array}$ & $\begin{array}{l}\text { 11. Related PO No. } \\
\text { N/A }\end{array}$ \\
\hline \multirow{2}{*}{\multicolumn{2}{|c|}{$\begin{array}{l}\text { 12a.-Modification-Work-... } \\
\text { [] Yes (fill out Blk. } \\
\text { 12b) } \\
{[X] \text { No (NA Blks. 12b, }} \\
\text { 12c, 12d) }\end{array}$}} & \multirow{2}{*}{$\begin{array}{c}-12 \mathrm{~b}: \text { Work Package } \\
\text { No. } \\
\text { N/A } \\
\end{array}$} & \multicolumn{2}{|c|}{$\begin{array}{l}\text { 12c. Modification Work Complete } \\
\qquad N / A\end{array}$} & $\begin{array}{l}\text { 12d. Restored to Originat Condi-: } \\
\text { tion (Temp. or Standby ECN only) } \\
\text { N/A }\end{array}$ \\
\hline & & & $\begin{array}{l}\text { Design Authority/Cog. Engineer } \\
\text { Signature \& Date }\end{array}$ & \multicolumn{2}{|c|}{$\begin{array}{c}\text { Design Authority/Cog. Engineer } \\
\text { signature \& Date }\end{array}$} \\
\hline
\end{tabular}

14a. Justification (mark one)

Criteria Change [] Design Improvement

As-Found

[X]

Facilitate const

Environmental

[]

Facility Deactivation

[]

14b. Justification Details

To prevent confusion, the references in the document to the use of the furnaces in $H A-$ 21 I were deleted. When the installation of the thermal stabilization equipment in HA-

$21 \mathrm{I}$ is complete, the referenced document will be updated.

15. Distribution (include name, MSIN, and no. of copies)

See Distribution Sheet 


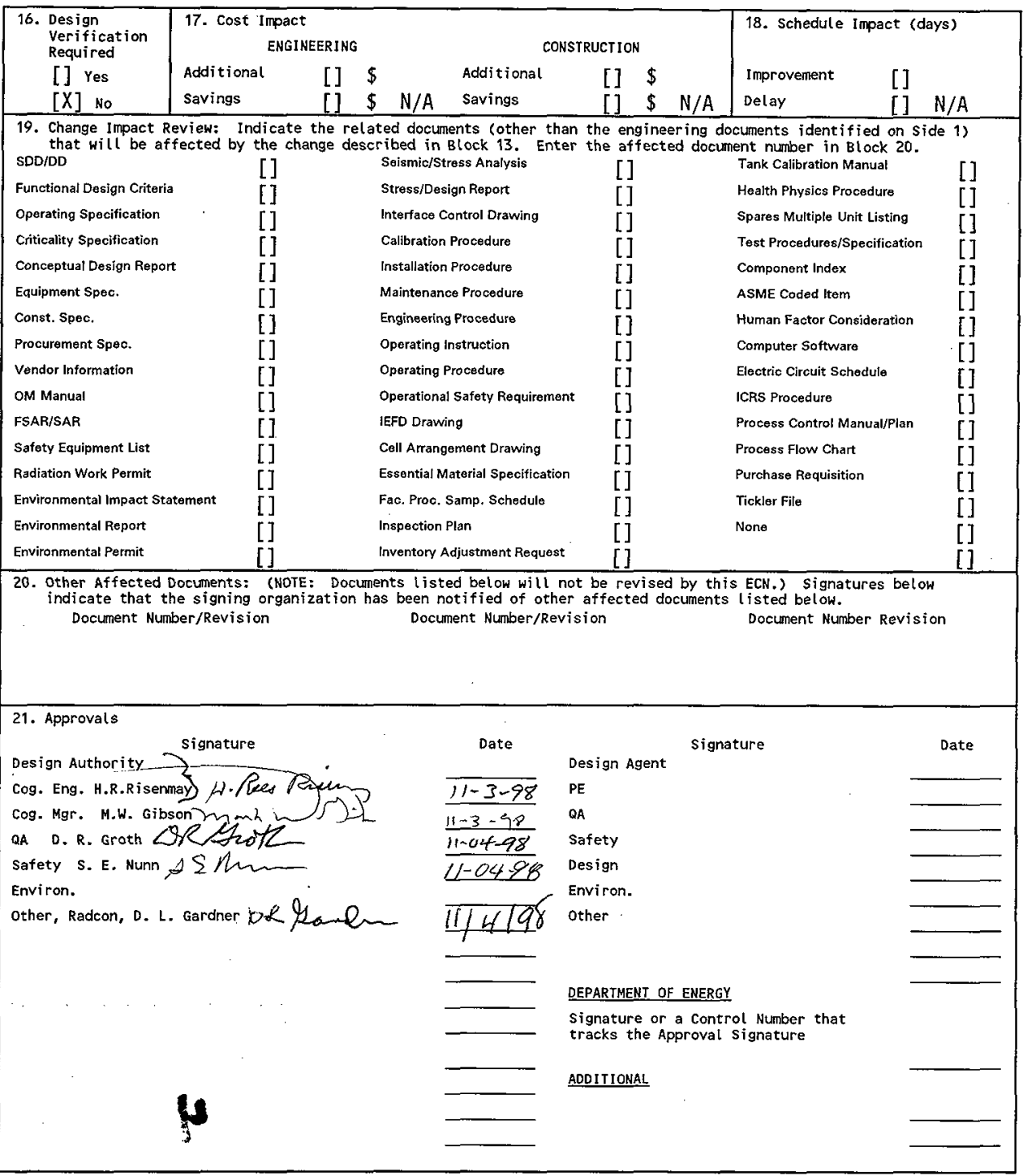


1. Identification Number:

WHC-SD-CP-SDD-017, Rev. 3

\section{USQ SCREENING}

Page 1 of 2

2. Title: SYSTEM DESIGN DESCRIPTION PFP THERMAL STABILIZATION

INSTRUCTIONS: Respond to each question and provide justification for each response. A restatement of the question does not constitute a satisfactory justification or basis. An adequate justification provides sufficient explanation such that an independent reviewer could reach the same conclusion based on the information provided [DOE 5480.21, 10.e.1].

The authorization basis documents reviewed included those listed in FSP-PFP-5-8, Section 2.23, Appendix A. These are:

WHC-SD-CP-SAR-021 Revision 0-J and supplemental ECN's below

ECN-646623 ECN-616618 ECN 649956

ECN-646804 ECN-708423 ECN 649958

ECN-611939 ECN-643207

ECN-191508 ECN-629275

ECN-649765 ECN-649770

$\mathrm{ECN}-642356 \quad \mathrm{ECN}-631022$

WHC-SD-CP-OSR-010, Revision 0-H

DOE/DP-0130, January 1995

HNF-2024, Rev 0-A

Letter FDH-9755047 R2, October 10, 1997

DOE-RL Letter 97-TPD-163, August 22, 1997

\section{QUESTIONS}

1.Does the proposed change or occurrence represent a change to the facility or procedures as described in the Authorization Basis?

[] N/A [X] No [] Yes/Maybe

BASIS: Handling of thermally stabilized material is considered normal operations. Section 6.2.2 and 6.4.1.2 of the Authorization Basis (WHC-SD-CP-SAR-021, Rev 0-H) discusses the thermal stabilization process. The changes being made to the SDD document were to delete the references to the use of the furnaces in glovebox HA-21I. The Installation of thermal stabilization equipment in HA-21I has not been completed. To avoid potential confusion the references to HA-21I were deleted. Other typos were corrected and clarifications to the design description were made. This document change does not represent any change to conditions described in the Authorization Basis.

2.Does the proposed change or occurrence represent conditions that have not been analyzed in the Authorization Basis?

[] N/A [X] No [] Yes/Maybe

BASIS: Handling of stabilized material does not go beyond any conditions mentioned in 
1. Identification Number:

WHC-SD-CP-SDD-017, Rev. 3

2. Title: SYSTEM DESIGN DESCRIPTION PFP THERMAL STABILIZATION

WHC-SD-CP-SAR-021, Rev.0. Spills of plutonium bearing materials are covered in section 9.1.3, Radioisotope-Bearing Powder Spills, and no new accident could be caused by the changes made to the document. Changes to this document do not represent a change to the Authorization Basis.

3.Does the proposed change represent a test or experiment NOT described in the Authorization Basis that may affect the safe operation of the facility?

$[\mathrm{X}] \mathrm{N} / \mathrm{A} \quad[]$ No [] Yes/Maybe

BASIS: The change to the document does not comprise a test or experiment.

4.Does the proposed change or occurrence represent a change to the Technical Safety Requirements or a reduction in the margin of safety defined in the Technical Safety Requirements?

[] N/A [X] No [] Yes/Maybe

BASIS: Deleting the references to HA-21I in the SDD does not represent or require any changes to WHC-SD-CP-OSR-010, Rev A-4. No Safety Limits for PFP are specified in OSR-10 so a margin of safety cannot be affected.

USQE \#1 $\underline{\text { H. R. Risenmay }}$ (Print Name)

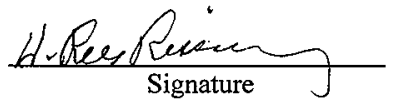

Date: October 27,1998
USQE \#2

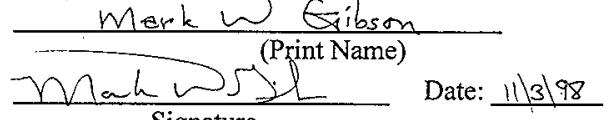

Signature

If there is a YES/MAYBE response to questions 1, 2, 3, or 4, then a USQ Evaluation must be completed.

The following guidance should be considered when completing this screening. This guidance should not be considered all-inclusive; additional factors may need to be considered depending on the nature of the proposed change.

Does the proposed change:

1) Modify, add, or delete a safety class function of a structure, system or component stated in the authorization basis?

2) Alter the design of a structure, system or component as described in the authorization basis?

3) Modify, add, or delete the description of operation, operating environment, or analyses of any system or component described in the authorization basis?

4) Modify, add, delete or conflict with any of the design bases stated in the authorization basis?

5) Conflict with the principle or general design criteria stated in the authorization basis?

6) Modify, add, or delete any plant design features described in the authorization basis?

7) Modify, add, or delete a flow diagram or facility drawing provided in the authorization basis?

8) Create the potential for new system or component interactions (e.g., seismic, electrical breaker coordination)? 


\title{
SYSTEM DESIGN DESCRIPTION PFP THERMAL STABILIZATION
}

\section{H. Rees Risenmay}

B\&W Hanford Company, Richland, WA 99352

U.S. Department of Energy Contract DE-AC06-96RL13200

\author{
EDT/ECN: 637055 \\ Org Code: 15530 \\ B\&R Code: EW7040000 \\ UC: 2050 \\ Charge Code: 100741 \\ Total Pages: 3635 \\ pF $11-10-98$
}

Key Words: Thermal Stabilization, HC-21C, Plutonium Residues

Abstract: The purpose of this document is to provide a system design description and design basis for the Plutonium Finishing Plant (PFP) Thermal Stabilization project. The sources of material for this project are residues scraped from glovebox floors and materials already stored in vault storage that need further stabilizing to meet the 3013 storage requirements. Stabilizing this material will promote long term storage and reduced worker exposure. This document addresses: function design, equipment, and safety requirements for thermal stabilization of plutonium residues and oxides.

Lexan is a registered trademark of the General Electric Co.

IRADEMARK DISCLAIMER. Reference herein to any specific commercial product, process, or service by trade name, trademark, manufacturer, or otherwise, does not necessarily constitute or imply its endorsement, recommendation, or favoring by the United States Government or any agency thereof or its contractors or subcontractors.

Printed in the United States of America. To obtain copies of this document, contact: Document Control Services, P.0. Box 950, Mailstop H6-08, Richland WA 99352, Phone (509) 372-2420; Fax (509) 376-4989.
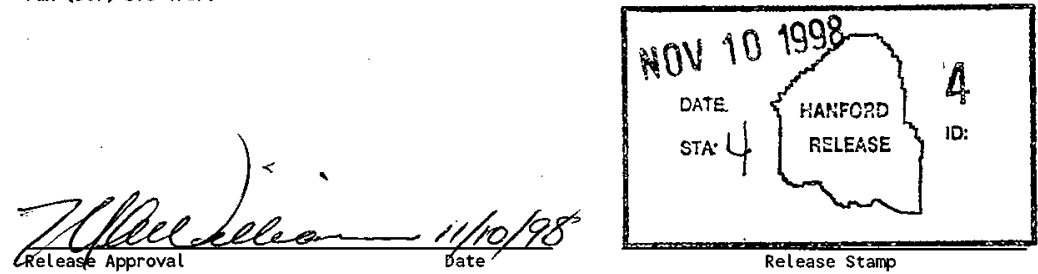


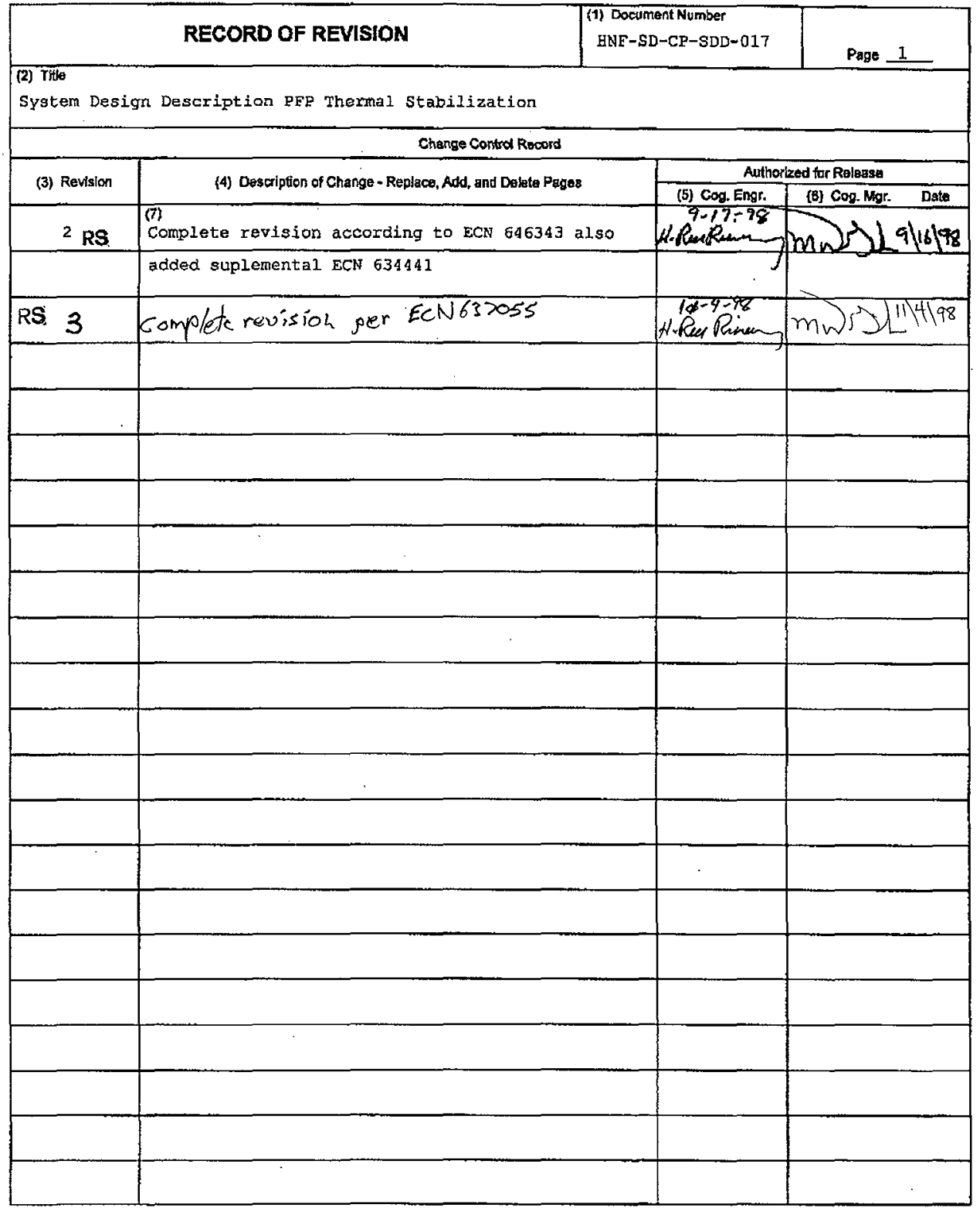


HNF-SD-CP-SDD-017

REV. 73

d: 14

SYSTEM DESIGN DESCRIPTION

PFP THERMAL STABILIZATION 


\section{TABLE OF CONTENTS}

1.0 PURPOSE 4

2.0 SUMMARY 4

3.0 FUNCTIONS AND DESIGN REQUIREMENTS .5

3.1 PROCESS REQUIREMENTS

3.2 INTERFACES 6

4.0 SAFETY INTERLOCKS, SET POINTS, AND ALARMS .8

4.1 SAFETY INTERLOCKS. 8

4.2 SET POINTS/RANGES. .9

4.3 ALARM RESPONSE.

5.0 OPERATION

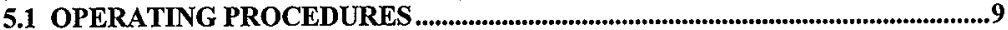

5.2 OPERATING SPECIFICATIONS DOCUMENT …..........................................10

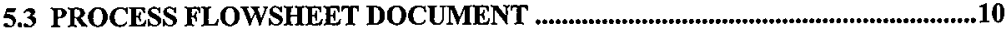

6.0 MAINTENANCE

6.1 MAINTENANCE PROCEDURES

6.2 VENDOR INFORMATION FILES

7.0 SURVEILLANCE.

8.0 SAFETY .15

8.1 FIRE SAFETY 16

8.2 EXCESSIVE HEAT

8.3 CRITICALITY 18

8.4 RADIATION SAFETY

9.0 EQUIPMENT SAFETY CLASS ANALYSIS

9.1 HC-21C GLOVEBOX FURNACE TEMPERATURE CONTROL SYSTEM 19

9.2 HC-21C GLOVEBOX FURNACE EMERGENCY SHUTDOWN

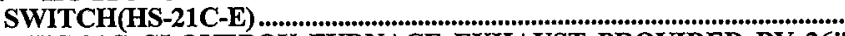

9.3 HC-21C GLOVEBOX FURNACE EXHAUST PROVIDED BY 26"

PROCESS VACUUM SYSTEM.

9.4 HC-21C GLOVEBOX FURNACE CO2 SUPPLY SYSTEM

9.5 HC-21C GLOVEBOX HIGH TEMPERATURE CONTROL SYSTEM 21

9.6 HC-21C GLOVEBOX FURNACES. 22

9.7 HC-21C CONTROL PANEL HAND SWITCHES .22

9.8 HC-21C TEMPERATURE CONTROL ITEMS. .23

9.9 HC-21A TEMPERATURE SENSOR AND ALARM 23 
APPENDIX A SYSTEM DRAWING LIST .........................................................................................25

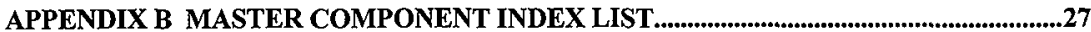

OMEGA is a register trademark of Omega Engineering, Inc, Stamford, CT

Lexan is a register trademark of General Electric Company, Pittsfield, PA

Pall Advanced Separations Systems is a register trademark of Pall Corporation, Glen Cove, NY Thermolyne is a register trademark of Citibank, NA, New York, NY

General Electric is a register trademark of General Electric Company, Schenectady, NY

Halon is a register trademark of Ausimont USA Inc., Waltham, MA

Allen-Bradley is a register trademark of Allen-Bradley Company, Inc. Milwaukee, Wisconsin Concoa is a register trademark of Controls Corporation of America, Virginia Beach, VA Whitey is a register trademark of Swagelok Company, SOLON, $\mathrm{OH}$ Ladish Co. is a register trademark of General Electric Capital Corporation, Chicago, IL Ashcroft is a register trademark of Dresser Industries, Inc. Dallas TX 
HNF-SD-CP-SDD-017

Rev. 3

\subsection{PURPOSE}

The purpose of this document is to provide a system design description (SDD) and design basis for the Plutonium Finishing Plant (PFP) Thermal Stabilization project. The chief objective of the SDD is to document the Structures, Systems, and Components (SSCs) that establish and maintain the facility Safety Envelope necessary for normal safe operation of the facility; as identified in the FSAR, the OSRs, and Safety Assessment Documents (SADs). This safety equipment documentation should satisfy guidelines for the SDD given in WHC-SD-CP-TI-181, Criteria for Identification and Control of Equipment Necessary for Preservation of the Safety Envelope and Safe Operation of PFP.

The basis for operational, alarm response, maintenance, and surveillance procedures are also identified and justified in this document. This document and its appendices address the following elements of the PFP Thermal Stabilization project:

- Functional and design requirements

- Design description

- Safety Envelope Analysis

- Safety Equipment Class

- Operational, maintenance and surveillance procedures

The appendices contain additional data for informational purposes only. The actual data bases and/or supporting documents should be consulted for the most current data.

\subsection{SUMMARY}

The Thermal Stabilization Project is designed to stabilize the plutonium bearing materials currently stored in gloveboxes and plutonium bearing materials in product storage vaults at the PFP to meet interim storage as defined by DOE-HQ Standard DOE-STD-3013. Stabilizing this material will facilitate long term storage and reduce worker exposure.

The sources of plutonium bearing material for this project are residual materials scraped from glovebox floors, glovebox floor sweepings, and vault storage material ( $\mathrm{Pu}-\mathrm{U}$ mixtures) that need further stabilization. These materials accumulated during the production of defense material at the PFP. The plutonium bearing material is currently contained in $1 / 2$ liter capped plastic bottles, called polyjars, small slip-lid cans stored in various gloveboxes, or in cans in the storage vaults. The material will be thermally stabilized in gloveboxes $\mathrm{HC}-21 \mathrm{C}$ (room 230A) and HA-21I (room 235) of the 234-5Z building. Processed material, after cooling, will then be packaged in glovebox HC-18M (room 228C), bagged out and canned for interim storage in vaults at the PFP. 
The furnace related equipment installed by the Thermal Stabilization project has been determined not to be Safety Class or Safety Significant based upon the facility safety analysis report WHC-SD-CP-SAR-021and the safety classification process as driven by PRO-704, Rev. 0 , Hazard and Accident Analysis Process, Section 2.4, Table 5 and Appendix F. However, the gloveboxes, ventilation system, and room Continuous Air Monitors (CAM) are safety significant equipment. No accident has been postulated that would affect on site or off-site personnel, however, so there is no requirement for a safety class designation.

\subsection{FUNCTIONS AND DESIGN REQUIREMENTS}

Reactive Plutonium bearing materials (other than metal items), usually stored in polyjars, are first sealed into glovebox HC-21A; where packaging is removed and the material is weighed and placed into a carrier called a boat. The boat is then transferred through conveyor $\mathrm{HC}-2$ to glovebox $\mathrm{HC}-21 \mathrm{C}$ and placed into one of the muffle furnaces.

If the material to be processed originated in the Plutonium Reclamation Facility (PRF), the material potentially contains tributyl phosphate (TBP). The daily operation instruction that designates the items to be processed will also specify when those items require organic analysis. When the analysis shows organic present the amount of organic per furnace batch will be examined to ensure that the 10 gram limit is not exceeded. For this type of material a rotameter is adjusted to provide a specified flow rate of carbon dioxide $\left(\mathrm{CO}_{2}\right)$ purge gas into the furnace. The purpose of the $\mathrm{CO}_{2}$ is to dilute any butene which could be generated from the degradation of TBP in the PRF material. The off-gas is removed from the furnace via the 26 inch vacuum system at a specified rate.

The next step involves starting the furnace heating cycle from the control panel for glovebox HC-21C. The operator assures that the emergency stop button for glovebox HC-21C is not depressed and that the furnace door is closed. The operator then selects the correct cycle program on the controller or operator display screen for the feed material being processed and depresses the manual start switch.

The controller has been pre-programmed to ramp and hold the furnace temperature at rates and temperature levels specific to the material being processed. The material is then cooled and transported to glovebox $\mathrm{HC}-18 \mathrm{M}$ via conveyors $\mathrm{HC}-2$ and $\mathrm{HC}-18 \mathrm{BS}$. In HC-18M the product is ground (if needed), blended, sampled (to verify the Loss on Ignition (LOI) meets vault storage specifications), and packaged in the PUREX slip lid can for long term storage. The packaged material is moved to the HC-18BS glovebox for interim storage while waiting for the results of the sample analysis. Samples are analyzed for moisture content in the analytical labs. After the processed material has been analyzed, it is moved back to $\mathrm{HC}-18 \mathrm{M}$, bagged out to room $228 \mathrm{C}$, and placed in two hermetically sealed cans. The final can is weighed, security seals 
applied and either, transported to 175 vault for interim storage before being moved to $2736-\mathrm{ZB}$ or moved directly to $2736-\mathrm{ZB}$ for NDA and storage.

\subsection{PROCESS REQUIREMENTS}

Process requirements for Thermal Stabilization specify what types of material may be processed, process conditions for each type, and what specifications the finished product must meet. An important feed criterion is the percent organic in the material. Important finished product criteria are the amount of volatile compounds in the material (as determined by a percent Loss On Ignition (LOI) analysis), the size of processed particles, and the moisture absorption rate of the material. Process requirements for this system are defined and explained in.PFD-Z-10900004, Thermal Stabilization Process Flow sheet, 234-5Z Building ${ }^{1}$ and OSD-Z-184-00006 Thermal Stabilization ${ }^{2}$.

\subsection{INTERFACES}

Materials will be transferred to and from the vaults on a daily basis during normal operations. Vault 175 will be used as a staging area for both feed and product.

Off-gas streams from the furnaces in glovebox HC-21C are removed using the 26 " vacuum system.

Gases enter and leave the $\mathrm{HC}-18 \mathrm{M}, \mathrm{HC}-21 \mathrm{~A}$ and $\mathrm{HC}-21 \mathrm{C}$ gloveboxes through several systems. HC-21A has inlet streams consisting of E-4 "dry" air supply (Note: The E-4 system no longer supplies dry air, air is supplied at atmospheric humidity). Air will exit the HC-21A glovebox through a local HEPA filter before entering the E-4 exhaust system. Glovebox HC-18M is also supplied by the above "dry" air system and exhausted through the E-4 system. Glovebox HC$21 \mathrm{C}$ is also supplied by the dry air system and exhausted through the E-4 system. In addition, $\mathrm{CO}_{2}$ will enter $\mathrm{HC}-21 \mathrm{C}$ from tanks located in room $230 \mathrm{~A}$. $\mathrm{CO}_{2}$ is supplied directly to the furnaces inside the glovebox and leaves the furnaces and glovebox through the 26 " process vacuum system.

\subsubsection{Power}

Power is supplied to glovebox $\mathrm{HC}-21 \mathrm{C}$ and the Thermal Stabilization control panel through junction box JB-HC-21C. The junction box is located underneath HC-21C and is supplied by power panel " $\mathrm{B}$ "; part of the Remote Mechanical ' $\mathrm{C}$ ' (RMC) electrical system. Power for the system is routed first to the control panel and then relayed to furnaces, thermocouples, etc. Power to the electric can opener, oxygen monitors, and door lock latches, in HC-21A is through panelboard ARS-2 on the 235 mezzanine. 
Power to the balance and grinder in glovebox $\mathrm{HC}-18 \mathrm{M}$ is provided by the outlets located in the glovebox. HC-18M is a maintenance glovebox and has power outlets to operate various maintenance devices. Power is supplied by panel board $120 \mathrm{~B}$ on the mezzanine near column D9.

\subsubsection{Control}

All of the instrumentation, controls and alarms for $\mathrm{HC}-21 \mathrm{C}$ have been installed in a control panel which is located in room $230 \mathrm{~A}$, facing glovebox $\mathrm{HC}-21 \mathrm{C}$.

\subsubsection{Furnace Temperature}

Furnace temperature is measured by a thermocouple (TC). The furnaces in glovebox $\mathrm{HC}-21 \mathrm{C}$ have digital temperature controllers with set point programming which will receive input from the $\mathrm{TC}$ and, based on a comparison with the set point, send output to a silicon controlled rectifier (SCR). The SCR uses input from the temperature controller to establish an output amperage to the furnace. A deviation band alarm feature in the temperature controller is interlocked with power to the furnace and will disable the furnace when the measured temperature deviates outside the temperature band.

A redundant thermocouple located in each furnace provides input to a high temperature alarm switch (TAS). To prevent "burning out" furnace heating elements the TAS is interlocked to remove power from the furnace if the temperature exceeds a high set point.

When a deviation exists or the set point is exceeded the furnace interlock is accompanied by an audible alarm and a lighted window on an annunciator panel.

\subsubsection{Glovebox Temperature}

The glovebox temperature for $\mathrm{HC}-21 \mathrm{C}$ is measured by three thermocouples placed throughout the glovebox. The measured temperatures are sent to a high temperature select instrument which digitally displays each temperature for several seconds. When the temperature from any one of the three TCs reaches a setpoint (set well below the $93 \mathrm{C}(200 \mathrm{~F})$ trip point of the Halon system), power is removed from the furnaces. When the set point is exceeded it is accompanied by an audible alarm and a lighted window on the annunciator panel.

\subsubsection{Furnace Door Interlock}


The furnace door is interlocked to disable power to the furnace if the door is open. When the door is closed a red light on the panel lights up or the door of the furnace on the operator display screen closes, indicating that a heating cycle my be started. If the door is opened during a heating cycle, power to the furnace will be removed. This interlock prevents the furnace from inadvertently being turned on when the door is open.

\subsection{SAFETY INTERLOCKS, SET POINTS, AND ALARMS}

\subsection{SAFETY INTERLOCKS}

The safety interlocks described below control power to Furnaces

FUR-21C-1 and FUR-21C-2 in glovebox HC-21C. These interlocks are shown in drawing H-2815184 SH. $1 \& 2$.

Interlocks for Glovebox $\mathrm{HC}-21 \mathrm{C}$

General

Power will be removed from both furnaces (FUR-21C-1, FUR-21C-2) when any of the following conditions occur:

1. Emergency Push-Pull Switch (HS-21C-E) is depressed.

2. High Glovebox Temperature is detected (TAS-21C-C).

Interlocks for FUR-21C-1

In addition to the conditions for the General Interlocks 1 and 2 given above, power will be removed from Furnace \#1 (FUR-21C-1). when any of the following conditions occur:

A. High furnace temperature is detected (TAS-21C-A).

B. Deviation between set point and actual furnace temperature is detected (TIC-21CA).

C. Furnace Door \#1 is open (Limit Switch LS-21C-1).

Interlocks for FUR-21C-2

In addition to the conditions for the General Interlocks 1 and 2 given above, power will 
be removed from Furnace \#2 (FUR-21C-2) when any of the following conditions occur:
A. High furnace temperature is detected (TAS-21C-B).
B. Deviation between set point and actual furnace temperature is detected (TIC-21C- B).
C. Furnace Door \#2 is open (Limit Switch LS-21C-2).

\subsection{SET POINTS/RANGES}

Set points and ranges for furnace temperatures, alarms, etc. have been outlined in OSD-Z184-00006, the operating specifications document (OSD) for the Thermal Stabilization project ${ }^{2}$. The OSD also identifies off-standard conditions and recovery actions. Specific set points and ranges will not be stated here in order to avoid inconsistencies between this document and the OSD.

\subsection{ALARM RESPONSE}

Alarms associated with thermal stabilization activities will display on an annunciator panel of the control panel in Room 230A. Alarm response operator actions for the Thermal Stabilization process are documented in ZAR-020.

\subsection{OPERATION}

\subsection{OPERATING PROCEDURES}

- ZO-160-032, HC-21C Muffle Furnace Operation. This procedure provides instructions for stabilizing inorganic reactive plutonium bearing solid materials by oxidizing/heating these solids.

- ZO-160-034, Stabilized Material Handling. This procedure provides instructions for separating different sizes of stabilized plutonium bearing solids that have been processed through the muffle furnace.

- ZO-160-035, Furnace Charge Preparation. This procedure provides instructions for loading the thermal stabilization boats with material to be processed in the stabilization furnaces.

- ZAR-020, HC-21C Muffle Furnace Alarms. This procedure provides instructions for emergency shutdown and alarm responses for $\mathrm{HC}-21 \mathrm{C}$ furnaces in Rooms $230 \mathrm{~A}$. 


\subsection{OPERATING SPECIFICATIONS DOCUMENT}

- OSD-Z-184-00006, PFP Operating Specifications Document, Thermal Stabilization. This document contains specification limits for feed items, furnace and glovebox temperatures, charge size, and amount of combustible materials in the glovebox. Information detailing detection/control of process variables and recovery actions are also given.

\subsection{PROCESS FLOWSHEET DOCUMENT}

- PFD Z-190-00004, Thermal Stabilization Process Flowsheet. The Process Flowsheet Document (PFD) contains detailed information on process parameters and design. It includes equipment description, process technology, control schemes and set points, off-standard conditions, and safety concerns. ${ }^{13}$

\subsection{MAINTENANCE}

\subsection{MAINTENANCE PROCEDURES}

Calibration maintenance activities are initiated using the PMS system and PSCP and other general calibration procedures. Listed below are specific procedures used in the Thermal Stabilization system.

ZCP-4-001 Dwyer Magnehelic Differential Pressure Series 2000 and Capsehelic Differential Pressure Series 4000.

1-ZM-079; $\quad$ Muffle Furnace Temperature Control System Calibration

2Z-18364 Balances - Product Handling Verification System 74

\subsection{VENDOR INFORMATION FILES}

The vendor information (VI) file is compiled to address all of the components installed for Thermal Stabilization of plutonium bearing materials in gloveboxes $\mathrm{HC}-21 \mathrm{~A}, \mathrm{HC}-21 \mathrm{C}$, and $\mathrm{HC}-$ $18 \mathrm{M}$. The VI file is:

CVI Number Description 
HNF-SD-CP-SDD-017

Rev. 3

22592

Control Panel

Temperature Control System

Instrumentation

Associated Piping and Valves

Furnaces

Off-gas Filters

$\mathrm{CO}_{2}$ supply manifold

Programmable Logic Controller (PLC)

Filter housings

Grinder

Commercial Can Opener

Oxygen sensor interlock system

\subsection{SURVEILLANCE}

Surveillance of Safety Class and other equipment is controlled and monitored through the Preventative Maintenance System (PMS). The PMS is a large database which tracks when equipment surveillance needs to occur and what information needs to be recorded. This database also contains historical data (past calibration or functional checks) for the equipment. The following table lists all System 73T equipment in the PMS database and the surveillance interval.

\begin{tabular}{|c|c|c|c|c|}
\hline $\begin{array}{c}\text { LOOP } \\
\text { NUMB } \\
\text { ER }\end{array}$ & $\begin{array}{c}\text { SEQUEN } \\
\text { CE } \\
\text { NUMBE } \\
\mathrm{R}\end{array}$ & $\begin{array}{c}\text { INSTRUMENT } \\
\text { IDENTIFICATIO } \\
\mathrm{N}\end{array}$ & FUNCTION & $\begin{array}{c}\text { VERIFICATIO } \\
\text { N INTERVAL }\end{array}$ \\
\hline BO410 & 1 & TIC-21C-A & $\begin{array}{c}\text { TEMPERATURE } \\
\text { CONTROLLER FUR-1 }\end{array}$ & 12 MONTHS \\
\hline & 2 & TR-21C & $\begin{array}{c}\text { TEMPERATURE RECORDER, } \\
\text { CHANNEL 1, FUR-1 } \\
\text { TEMPERATURE }\end{array}$ & 12 MONTHS \\
\hline & 3 & TE-21C-5 & $\begin{array}{c}\text { THERMOCOUPLE FOR FUR-1 } \\
\text { CONTROLLER, TYPE K }\end{array}$ & $\begin{array}{c}\text { PRE- } \\
\text { CAL/CERT }\end{array}$ \\
\hline & 4 & TA-21C-1 & $\begin{array}{c}\text { DEVIATION ALARM FUR-1, } \\
\text { WINDOW 4-B }\end{array}$ & 12 MONTHS \\
\hline
\end{tabular}


HNF-SD-CP-SDD-017

Rev. 3

\begin{tabular}{|c|c|c|c|c|}
\hline \multirow[t]{8}{*}{$\begin{array}{l}\text { LOOP } \\
\text { NUMB } \\
\text { ER }\end{array}$} & $\begin{array}{c}\text { SEQUEN } \\
\text { CE } \\
\text { NUMBE } \\
\text { R }\end{array}$ & $\begin{array}{l}\text { INSTRUMENT } \\
\text { IDENTIFICATIO } \\
\mathrm{N}\end{array}$ & FUNCTION & $\begin{array}{l}\text { VERIFICATIO } \\
\text { N INTERVAL }\end{array}$ \\
\hline & 5 & EIC-21C-A & $\begin{array}{c}\text { SOLID STATE CONTACTOR } \\
\text { FUR- } 1\end{array}$ & $\begin{array}{c}\text { PRE- } \\
\text { CAL/CERT }\end{array}$ \\
\hline & 6 & HS-21C-A & $\begin{array}{c}\text { MANUAL START BUTTON } \\
\text { FUR-1 }\end{array}$ & 12 MONTHS \\
\hline & 7 & HS-21C-B & $\begin{array}{l}\text { MANUAL STOP BUTTON } \\
\text { FUR-1 }\end{array}$ & 12 MONTHS \\
\hline & 8 & TAS-21C-A & $\begin{array}{l}\text { HIGH TEMPERATURE } \\
\text { ALARM SWITCH, FUR-1 }\end{array}$ & 12 MONTHS \\
\hline & A & TE-21C-4 & $\begin{array}{l}\text { THERMOCOUPLE FOR FUR-1 } \\
\text { HIGH TEMPERATURE } \\
\text { ALARM, TYPE K }\end{array}$ & $\begin{array}{l}\text { PRE- } \\
\text { CAL/CERT }\end{array}$ \\
\hline & B & TA-21C-4 & $\begin{array}{c}\text { HIGH TEMPERATURE } \\
\text { ALARM FUR-1, WINDOW 4-A }\end{array}$ & 12 MONTHS \\
\hline & $\mathrm{C}$ & LS-21C-1 & DOOR LIMIT SWITCH, FUR-1 & 12 MONTHS \\
\hline \multirow[t]{7}{*}{ BO411 } & 1 & TIC-21C-B & $\begin{array}{c}\text { TEMPERATURE } \\
\text { CONTROLLER FUR-2 }\end{array}$ & 12 MONTHS \\
\hline & 2 & TR-21C & $\begin{array}{c}\text { TEMPERATURE RECORDER, } \\
\text { CHANNEL 2, FUR-2 } \\
\text { TEMPERATURE }\end{array}$ & 12 MONTHS \\
\hline & 3 & TE-21C-6 & $\begin{array}{l}\text { THERMOCOUPLE FOR FUR-2 } \\
\text { CONTROLLER, TYPE K }\end{array}$ & $\begin{array}{l}\text { PRE- } \\
\text { CAL/CERT }\end{array}$ \\
\hline & 4 & TA-21C-6 & $\begin{array}{l}\text { DEVIATION ALARM FUR-2, } \\
\text { WINDOW 6-B }\end{array}$ & 12 MONTHS \\
\hline & 5 & EIC-21C-B & $\begin{array}{l}\text { SOLID STATE CONTACTOR } \\
\text { FUR-2 }\end{array}$ & $\begin{array}{c}\text { PRE- } \\
\text { CAL/CERT }\end{array}$ \\
\hline & 6 & $\mathrm{HS}-21 \mathrm{C}-\mathrm{C}$ & $\begin{array}{c}\text { MANUAL START BUTTON } \\
\text { FUR-2 }\end{array}$ & 12 MONTHS \\
\hline & 7 & HS-21C-D & MANUAL STOP BUTTON & 12 MONTHS \\
\hline
\end{tabular}


HNF-SD-CP-SDD-017

Rev. 3

\begin{tabular}{|c|c|c|c|c|}
\hline \multirow[t]{6}{*}{$\begin{array}{l}\text { LOOP } \\
\text { NUMB } \\
\text { ER }\end{array}$} & $\begin{array}{l}\text { SEQUEN } \\
\text { CE } \\
\text { NUMBE } \\
\text { R }\end{array}$ & $\begin{array}{l}\text { INSTRUMENT } \\
\text { IDENTIFICATIO } \\
\mathrm{N}\end{array}$ & FUNCTION & $\begin{array}{l}\text { VERIFICATIO } \\
\text { N INTERVAL }\end{array}$ \\
\hline & & & FUR-2 & \\
\hline & 8 & TAS-21C-B & $\begin{array}{l}\text { HIGH TEMPERATURE } \\
\text { ALARM SWITCH, FUR-2 }\end{array}$ & 12 MONTHS \\
\hline & A & TE-21C-7 & $\begin{array}{l}\text { THERMOCOUPLE FOR FUR-2 } \\
\text { HIGH TEMPERATURE } \\
\text { ALARM, TYPE K }\end{array}$ & $\begin{array}{c}\text { PRE- } \\
\text { CAL/CERT }\end{array}$ \\
\hline & B & TA-21C-7 & $\begin{array}{l}\text { HIGH TEMPERATURE } \\
\text { ALARM FUR-2, WINDOW 6-A }\end{array}$ & 12 MONTHS \\
\hline & $\mathrm{C}$ & LS-21C-2 & DOOR LIMIT SWITCH, FUR-2 & $12 \mathrm{MONTHS}$ \\
\hline $\mathrm{B} 0412$ & 1 & HS-21C-E & EMERGENCY STOP BUTTON & 12 MONTHS \\
\hline \multirow[t]{5}{*}{ B0413 } & 1 & TAS-21C-C & $\begin{array}{l}\text { HIGH TEMPERATURE } \\
\text { ALARM SWITCH FOR } \\
\text { GLOVEBOX HC- } 21 \mathrm{C}\end{array}$ & 12 MONTHS \\
\hline & 2 & $\mathrm{TAH}-21 \mathrm{C}-2$ & $\begin{array}{l}\text { HIGH GLOVEBOX } \\
\text { TEMPERATURE ALARM, } \\
\text { WINDOW } 2\end{array}$ & 12 MONTHS \\
\hline & 3 & TE-21C-1 & $\begin{array}{c}\text { GLOVEBOX } \\
\text { THERMOCOUPLE } 1 \text {, TYPE J }\end{array}$ & $\begin{array}{l}\text { PRE- } \\
\text { CAL/CERT }\end{array}$ \\
\hline & 4 & $\mathrm{TE}-21 \mathrm{C}-2$ & $\begin{array}{c}\text { GLOVEBOX } \\
\text { THERMOCOUPLE 2, TYPE J }\end{array}$ & $\begin{array}{l}\text { PRE- } \\
\text { CAL/CERT }\end{array}$ \\
\hline & 5 & TE-21C-3 & $\begin{array}{c}\text { GLOVEBOX } \\
\text { THERMOCOUPLE 3, TYPE J }\end{array}$ & $\begin{array}{c}\text { PRE- } \\
\text { CAL/CERT }\end{array}$ \\
\hline \multirow[t]{2}{*}{ B0414 } & 1 & DPI-21C-1 & $\begin{array}{c}\text { DIFFERENTIAL PRESSURE } \\
\text { INDICATOR, FILTER ON } \\
\text { FUR-1 }\end{array}$ & 12 MONTHS \\
\hline & 2 & FI-21C-1 & $\begin{array}{c}\text { FLOW INDICATOR, FUR-1 } \\
\text { EXHAUST }\end{array}$ & 12 MONTHS \\
\hline
\end{tabular}


HNF-SD-CP-SDD-017

Rev. 3

\begin{tabular}{|c|c|c|c|c|}
\hline \multirow[t]{4}{*}{$\begin{array}{c}\text { LOOP } \\
\text { NUMB } \\
\text { ER }\end{array}$} & $\begin{array}{c}\text { SEQUEN } \\
\text { CE } \\
\text { NUMBE } \\
\text { R }\end{array}$ & $\begin{array}{c}\text { INSTRUMENT } \\
\text { IDENTIFICATIO } \\
\text { N }\end{array}$ & FUNCTION & $\begin{array}{l}\text { VERIFICATIO } \\
\text { N INTERVAL }\end{array}$ \\
\hline & 3 & PI-21C-1 & VACUUM GAGE & $\begin{array}{c}12 \\
\text { MONTHS }\end{array}$ \\
\hline & 4 & PI-21C-2 & VACUUM GAGE & $\begin{array}{c}12 \\
\text { MONTHS }\end{array}$ \\
\hline & 5 & DPI-21C-3 & $\begin{array}{l}\text { DIFFERENTIAL PRESSURE } \\
\text { INDICATOR ORIFICE ON } \\
\text { OFF-GAS FUR-21C-2 }\end{array}$ & $\begin{array}{c}12 \\
\text { MONTHS }\end{array}$ \\
\hline \multirow[t]{3}{*}{ B0415 } & 1 & DPI-21C-2 & $\begin{array}{c}\text { DIFFERENTIAL PRESSURE } \\
\text { INDICATOR, FILTER ON } \\
\text { FUR-2 }\end{array}$ & 12 MONTHS \\
\hline & 2 & $\mathrm{FI}-21 \mathrm{C}-2$ & $\begin{array}{c}\text { FLOW INDICATOR, FUR-2 } \\
\text { EXHAUST }\end{array}$ & $\begin{array}{c}\text { PRECERT/CA } \\
\text { L } \\
\text { INDICATION } \\
\text { ONLY }\end{array}$ \\
\hline & 3 & DPI-21C-4 & $\begin{array}{l}\text { DIFFERENTIAL PRESSURE } \\
\text { INDICATOR ORIFICE ON } \\
\text { OFF-GAS FUR-21C-2 }\end{array}$ & $\begin{array}{c}12 \\
\text { MONTHS }\end{array}$ \\
\hline \multirow[t]{4}{*}{ B0416 } & 1 & FI-21C-3 & $\begin{array}{c}\text { ROTAMETER, } \mathrm{CO}_{2} \text { SUPPLY } \\
\text { FUR-21C-1 }\end{array}$ & $\begin{array}{c}\text { PRECERT/CA } \\
\text { L } \\
\text { INDICATION } \\
\text { ONLY }\end{array}$ \\
\hline & 2 & FI-21C-4 & $\begin{array}{l}\text { ROTAMETER, } \mathrm{CO}_{2} \text { SUPPLY } \\
\text { FUR-21C-2 }\end{array}$ & $\begin{array}{c}\text { PRECERT/CA } \\
\text { L } \\
\text { INDICATION } \\
\text { ONLY }\end{array}$ \\
\hline & 3 & PRV-21C-1 & $\begin{array}{l}\text { PRESSURE REDUCING } \\
\text { VALVE, } \mathrm{CO}_{2} \text { SUPPLY }\end{array}$ & 12 MONTHS \\
\hline & 3 & PI-74-1 & $\begin{array}{c}\text { VACUUM INDICATOR FOR } \\
\text { HEADER }\end{array}$ & $\begin{array}{l}\text { ONE TIME } \\
\text { FUNCTIONAL } \\
\text { CHECK }\end{array}$ \\
\hline
\end{tabular}


HNF-SD-CP-SDD-017

Rev. 3

\begin{tabular}{|c|c|c|c|c|}
\hline $\begin{array}{l}\text { LOOP } \\
\text { NUMB } \\
\text { ER }\end{array}$ & $\begin{array}{c}\text { SEQUEN } \\
\text { CE } \\
\text { NUMBE } \\
\text { R }\end{array}$ & $\begin{array}{c}\text { INSTRUMENT } \\
\text { IDENTIFICATIO } \\
\mathrm{N}\end{array}$ & FUNCTION & $\begin{array}{l}\text { VERIFICATIO } \\
\text { N INTERVAL }\end{array}$ \\
\hline B0419 & 1 & FI-21A-2 & $\begin{array}{l}\text { IAC ARGON FLOW } \\
\text { INDICATOR }\end{array}$ & 12 MONTHS \\
\hline \multirow[t]{2}{*}{ B0420 } & 1 & TE-21A-1 & HC-21A TEMPERATURE RTD & $\begin{array}{l}\text { PRECERT/CA } \\
\text { L }\end{array}$ \\
\hline & 2 & TI-21A-1 & $\begin{array}{l}\text { HC-21A TEMPERATURE } \\
\text { INDICATOR }\end{array}$ & 12 MONTHS \\
\hline B0421 & 1 & AI-21A-1 & $\begin{array}{c}\text { IAC OXYGEN } \\
\text { MONITOR/INDICATOR }\end{array}$ & 12 MONTHS \\
\hline B0422 & 1 & $\mathrm{AI}-21 \mathrm{~A}-2$ & $\begin{array}{l}\text { AIRLOCK OXYGEN } \\
\text { MONITOR/INDICATOR }\end{array}$ & 12 MONTHS \\
\hline
\end{tabular}

\subsection{SAFETY}

The principle hazards associated with glovebox HA-21A, HC-18M, and HC-21C operations are fire safety, excessive heat, criticality, and radiation. The following section describes the potential hazards associated with thermal stabilization. In addition, glovebox HC$21 \mathrm{C}$ was analyzed for a deflagration of butene gas from the presence of TBP. The analysis determined that the deflagration was bounded by an existing safety analysis for glovebox MT- 5 .

There are no operational safety requirements (OSRs) associated with the PFP Thermal Stabilization System. The equipment installed by the Thermal Stabilization project was determined to be "other equipment important to safety".

Worker safety and accident analysis are documented in the MT-5 Glovebox analysis. The two bounding accident scenarios for the MT-5 system, and thus the Thermal Stabilization system, are: a fire within the glovebox, and the rapid decomposition of tributyl phosphate (TBP) leading to the formation of combustible gases and deflagration of the gas (glovebox $\mathrm{HC}-21 \mathrm{C}$ only).

Calculated consequences for glovebox fires were found to be within risk acceptance guidelines. The rapid decomposition of TBP leading to the formation of combustible gases was 
shown to be an incredible event. The probability of a seismically induced deflagration in glovebox MT-5 resulting from a design basis earthquake (DBE) and a small earthquake were quantified and shown to be incredible events.

For further detail on safety criteria, see WHC-SD-CP-SAR-021" Analysis Document section 9.2.2,WHC-SD-CP-PHA-003, HA-21I HAZOP Study.

\subsection{FIRE SAFETY}

\subsubsection{Glovebox Fire}

High furnace temperatures and the presence of combustible materials are factors which could lead to a glovebox fire in $\mathrm{HC}-21 \mathrm{C}$. If such a fire occurs in $\mathrm{HC}-21 \mathrm{C}$ or $\mathrm{HC}-$ $21 \mathrm{~A}$, the Halon fire suppression system is in the glovebox to ensure the fire is extinguished.

\subsubsection{Combustible Material}

To keep an uncontrolled fire from taking place, combustible material must be kept to a minimum within the gloveboxes. Since high temperatures are involved in this process, extra care must be taken not to damage the gloves by using hot mill gloves when touching hot surfaces. Gloves near the furnace must be pulled out of the glovebox before the heating cycle is started.

\subsubsection{Glovebox Temperature}

Thermocouples independent of the furnace control system monitor the glovebox temperature continuously. In glovebox $\mathrm{HC}-21 \mathrm{C}$ three thermocouples have been located throughout the glovebox. If the glovebox temperature reaches the set temperature, an interlock in the glovebox temperature monitor removes power to the muffle furnaces. If the glovebox temperature exceeds $93 \mathrm{C}(200 \mathrm{~F})$, the Halon fire suppression system is activated.

To aid in maintaining a low temperature in the glovebox, the muffle furnace door will be kept closed when the furnace is at higher temperatures.

\subsubsection{Flammability of Off-Gas}

Feed items that originated in PRF potentially contain TBP. One of the 
decomposition products of TBP is butene. Butene, in certain concentrations, can be flammable. Combustion of large amounts of butene gas could, in a worst case scenario, cause rupture of the glovebox. It is, however, unlikely that a sufficient quantity of gas could be generated to rupture the glovebox. Four independent barriers in glovebox HC$21 \mathrm{C}$ are in place to prevent flammable levels of gas. The four barriers are:

(1) All items originating from PRF (or if origin is uncertain) are sampled for organic content. Material with greater than 10 grams organic will not be used as feed stock.

(2) Removal and dilution of any flammable gases by continuous gas circulation through the furnace of about $120-125 \mathrm{ft}^{3} / \mathrm{hr}$.

(3) A cover gas of $\mathrm{CO}_{2}$ will be introduced into the furnaces in glovebox $\mathrm{HC}-21 \mathrm{C}$ in the temperature regime where flammable gas could be generated. The $\mathrm{CO}_{2}$ will be fed into the furnaces at a flow rate of about $30-35 \mathrm{ft}^{3} / \mathrm{hr}$. The amount of $\mathrm{CO}_{2}$ available will be verified prior to each cycle.

(4) The material will be slowly heated at a ramp rate of $5 \mathrm{C} /$ minute $(9 \mathrm{~F} / \mathrm{min})$ to $175 \mathrm{C}$ $(347 \mathrm{~F})$ and held at this temperature for 1.5 hours. This will assure that all of the TBP has decomposed prior to reaching the auto-ignition temperature of butene $(324 \mathrm{C}$ or $615 \mathrm{~F})$.

\subsubsection{Plugged Filter}

The filter on the exhaust line may become clogged if there is a release of particulate matter during a heating cycle. This reduces the permeability of the filter, thus decreasing the exhaust flow rate and increasing the probability of butene buildup in the furnaces in glovebox $\mathrm{HC}-21 \mathrm{C}$.

Prior to each heating cycle in glovebox HC-21C, the pressure differential across the ceramic filter and the exhaust flow rate are checked to assure adequate flow rate. If the exhaust flow rate is not adequate (minimum $120 \mathrm{cfh}$ ), or the pressure differential is too high, then the ceramic filter needs to be cleaned or replaced before the cycle is run. ${ }^{5}$ While plugging the filters is not a safety concern, plugging will reduce efficiency during cool down.

\subsection{EXCESSIVE HEAT}

\subsubsection{Glovebox Windows}


The windows in the gloveboxes are made of Lexan. This material will not warp under heat stress and is shatter resistant. ${ }^{11}$

\subsubsection{Glovebox Gloves}

Boat handling tools and hot mill over-gloves will be used when moving hot material and equipment. This is to protect the glovebox gloves and hence the operator.

\subsection{CRITICALITY}

Since plutonium is a fissile material, measures are taken to assure prevention of conditions which could lead to a criticality incident. A criticality prevention specification (CPS) has been prepared for gloveboxes HC-2, HC-18M, HC-18BS, HC-21A, and HC-21C to accommodate the Thermal Stabilization process. Limits on plutonium quantities, container volumes, and material spacings are specified in these CPSs and shall be strictly adhered to during operations.

\subsection{RADIATION SAFETY}

Operations around the gloveboxes are kept to a minimum to minimize exposures. A control station is located in Room $230 \mathrm{~A}$ roughly 7 feet from glovebox $\mathrm{HC}-21 \mathrm{C}$ to allow the operator to monitor the operations of this glovebox and still maintain spacing.

\subsubsection{Foaming}

Plutonium oxycarbonate (from oxalate) forms an intermediate liquid phase above $100 \mathrm{C}(212 \mathrm{~F})$. The material boils at about $180 \mathrm{C}(356 \mathrm{~F})$ and could foam over the top of the boat. The temperature is held at a lower temperature of $175 \mathrm{C}(347 \mathrm{~F})$ for an hour to allow for the majority of the liquid to be driven off. If material does foam over, a scraper and paint brush may be used to scrape and sweep material from the bottom of the furnace once it has cooled. This material is then mixed with the new feed material for the next heating cycle.

\subsection{EQUIPMENT SAFETY CLASS ANALYSIS}

Due to the remote possibility of hazardous chemicals or radio nuclides being released offsite in any accident scenario of the Thermal Stabilization system, it was determined that no System 73T components would be rated as Safety Class or Safety Significant. 
PFP Safety Class and Safety Significant equipment is listed in the PFP Safety Equipment List, WHC-SD-CP-TI-108 under Safety Equipment List (SEL). Items in the Thermal Stabilization system in gloveboxes $\mathrm{HC}-18 \mathrm{M}, \mathrm{HC}-21 \mathrm{C}$, and HA-21A, which have industrial health and safety or process control functions are discussed below.

\subsection{HC-21C GLOVEBOX FURNACE TEMPERATURE CONTROL SYSTEM}

Item: Temperature Controllers for Furnaces \#1 \& \#2.

TIC-21C-A, TIC-21C-B

Basis: The temperature controllers ramp power supply to the furnaces. Materials originating in PRF potentially contain TBP which produces butene vapor when it is heated. The heating rate controls the rate of gas vaporization in the Pu bearing material. Uncontrolled heating could create large quantities of butene gas, a flammable vapor, in a short period of time. A controlled heating rate is one of the engineered barriers which prevents gas concentration in the furnaces in glovebox $\mathrm{HC}-21 \mathrm{C}$ from reaching the flammability point.

Controlled temperature ramp up rates also prevent boil-over of liquid solutions, thus minimizing cleanup and dose rates.

Item: Temperature Elements (Thermocouples) and Alarm Annunciators

TE-21C-5, TE-21C-6, TA-21C-1 (ANN-2), TA-21C-6 (ANN-5)

Basis: Thermocouples for this system are important because they supply the temperature controllers with information. The alarm annunciator is also important because it notifies operators that furnace temperatures are deviating from program parameters and action may be necessary.

\subsection{HC-21C GLOVEBOX FURNACE EMERGENCY SHUTDOWN SWITCH (HS-21C-}

E)

Item: Hand switch for furnace heat emergency stop. 
HS-21C-E

Basis: This manual switch removes power from both furnaces. The emergency shutdown switch allows operators to stop a heating cycle to preclude the following: a Halon Fire Suppression System alarm, a butene gas buildup in a furnace, or any other abnormal condition.

\subsection{HC-21C GLOVEBOX FURNACE EXHAUST PROVIDED BY 26" PROCESS VACUUM SYSTEM}

Item: Flow Indicators on furnace off-gas system.

DPI-21C-3, DPI-21C-4

Basis: The off-gas system is an engineered barrier designed to keep butene concentration in the furnaces low. Differential pressure gages across orifices provide verification of the off-gas flow rate from the furnaces. Verification of off-gas flow prior to initiating a heating cycle is important to ensure the off-gas system is not plugged.

Item: Differential Pressure Indicators in the furnace off-gas system which measure differential pressure on the off-gas filters.

DPI-21C-1, DPI-21C-2

Basis: The off-gas system is designed to keep butene concentration in the furnaces low. The off-gas filters will remove particulates from this system before gas enters the heat exchangers and continues through the $26^{\prime \prime}$ process vacuum system. Filters clogged with particulate matter could decrease the off-gas flow rate, causing butene vapor to build up in the furnaces. The differential pressure indicators provide an indication of when filters are clogged and need to be cleaned or changed out.

\subsection{HC-21C GLOVEBOX FURNACE CO2 SUPPLY SYSTEM}

Item: Flow indicators on $\mathrm{CO}_{2}$ supply system.

FI-21C-3, FI-32C-4 
Basis: The $\mathrm{CO}_{2}$ supply system is an engineered barrier designed to eliminate the possibility of butene deflagration in a furnace. The supply system accomplishes this by keeping butene concentration in the furnaces low and by purging the furnace with a non-flammable gas. Flow indicators provide visual verification of the $\mathrm{CO}_{2}$ flow rate from storage tanks.

Item: Pressure Reducing Valve on $\mathrm{CO}_{2}$ supply system.

PRV-21C-1

Basis: The pressure reducing valve on the $\mathrm{CO}_{2}$ supply system must be functioning properly to ensure the necessary flow of $\mathrm{CO}_{2}$ to the furnaces.

\subsection{HC-21C GLOVEBOX HIGH TEMPERATURE CONTROL SYSTEM}

Item: Temperature Elements (Thermocouples), High Temperature Select Switch, and Alarm Annunciator

TE-21C-1, TE-21C-2, TE-21C-3, TAS-21C-C, TAH-21C-2 (ANN-3)

Basis: The glovebox high temperature control system ensures that furnace operations do not create high temperatures in the glovebox, thus causing the Halon Fire Suppression System to trip. The high temperature select switch (TAS-21C-C) is wired to an interlock which shuts off power to the furnaces when glovebox temperatures exceed set point limits.

The key component of this system is the high temperature select switch (TAS-21C-C). The switch monitors three thermocouples located in the HC-21C glovebox and alarms if any one thermocouple exceeds the set point limit. Thermocouples for this system are important because they supply the high temperature select switch with information. The alarm annunciator is also important because it notifies operators that glovebox temperatures are high and that the Halon Release Hold Button (HS-21C-HA) may need to be activated to stop Halon from being released. 


\subsection{HC-21C GLOVEBOX FURNACES}

Item: Furnaces $1 \& 2$

FUR-21C-1, FUR-21C-2

Basis: If the furnace fails for any reason the only consequence is that it will no longer be usable for stabilization. Power is supplied to the furnace by controllers and interlocks which have their own safety analysis.

Item: Limit switches on Furnaces $1 \& 2$.

LS-21C-1, LS-21C-2

Basis: These limit switches are located on the furnace doors and indicate whether the furnace door is open or closed. They are interlocked with the power supply such that power cannot reach the furnace if the furnace door is open. These limit switches are important because a furnace door left open during a heating cycle could cause the temperature in the glovebox to rapidly rise and activate the Halon Fire Suppression system. The limit switch also minimizes the risk of material (gloves, rags, etc.) coming in contact with hot furnace surfaces.

\subsection{HC-21C CONTROL PANEL HAND SWITCHES}

Item: Other Hand switches for process operation.

HS-21C-A, HS-21C-B, HS-21C-C, HS-21C-D

Basis: The other hand switches for manual start/stop of the furnaces are not safety class items because the emergency shutdown switch (HS21C-E) will remove power from either furnace should these buttons fail.

\subsection{HC-21C TEMPERATURE CONTROL ITEMS}


Item: Temperature Controller Contactor.

EIC-21C-A, EIC-21C-B

Basis: The temperature controller contactors control furnace power based on input from the temperature controllers. Their failure would result in no power feed to the furnaces; thus, the contactors could not be responsible for a power overload to the furnaces.

Item: Other Temperature Elements (Thermocouples), Alarm Switches, and Annunciators.

TE-21C-4, TE-21C-7, TAS-21C-A, TAS-21C-B, TA-21C-4, TA-21C-7

Basis: These thermocouples, alarm switches, and annunciators are designed to prevent burned out furnace heating elements from running at peak furnace power for an extended period of time. This system is also a redundant source of furnace temperature information and safety. The components are process control safeguards.

\subsection{HC-21A TEMPERATURE SENSOR AND ALARM}

Item: Temperature of glovebox HC-21A.

TE-21A-1, TI-21A-1

Basis: The temperature sensor is for monitoring the temperature of the HC-21A glovebox and alarming when the high temperature set point is surpassed. 


\subsection{REFERENCES}

1 PFD-Z-190-00004, Thermal Stabilization Process Flowsheet

2 OSD-Z-184-00006, PFP Operating Specification Document, Thermal Stabilization

3 ZO-160-032, HC-21C Muffle Furnace Operations

4 WHC-SD-CP-OCD-040, Basis Document for Sludge Stabilization

5 WHC-SD-CP-TRP-059, Scrap Stabilization Furnace Test Results, April 5, 1994

6 OSD-Z-184-00013, Special Nuclear Material Storage

7 CSER 94-007, Criticality Safety Engineering Report for Muffle Furnace Operations in Glovebox HC-211, Room 230C, 234-5Z Building

8 Progress Report NUMEC P-90, Development of Plutonium-Bearing Fuel Materials

9 IM 12840-89-CMK-199. Glovebox Selection for Plutonium Button Oxidation. K.E. Parker to C.M. Kronvall, November 2, 1989

10 Rockwell International Internal Letter from L.E. Edvalson to J.W. Patterson, February 13, 1986

11 WHC-SD-CP-SAR-021, Rev. 0. Plutonium Finishing Plant Final Safety Analysis Report (FSAR).

12 WHC-SD-CP-TI-108 Rev 13. PFP Safety Equipment List.

13 PFD-Z-190-00004. Thermal Stabilization Process Flowsheet, Room 230A, 2345Z Bldg. Rodgers, L. H. and W. S. Lewis. 6/23/94. 


\section{APPENDIX A}

SYSTEM DRAWING LIST

\begin{tabular}{|c|c|c|}
\hline $\begin{array}{l}\text { Drawing } \\
\text { Number }\end{array}$ & Index $\mathrm{No}$ & Title \\
\hline $\mathrm{H}-2-81310 \mathrm{SH} .1$ & 7501. & $\begin{array}{l}\text { GLOVEBOX HC-21C FURNACE } \\
\text { CONTROL CONSOLE ARRANGEMENT }\end{array}$ \\
\hline H-2-81310 SH. 2 & 7501 & $\begin{array}{l}\text { GLOVEBOX HC-21C FURNACE } \\
\text { CONTROL CONSOLE PANEL LAYOUTS }\end{array}$ \\
\hline H-2-81310 SH. 3 & 7301 & $\begin{array}{l}\text { GLOVEBOX HC-21C FURNACE } \\
\text { CONTROL PANEL LADDER DIAGRAM }\end{array}$ \\
\hline H-2-81310 SH. 4 & 7301 & $\begin{array}{l}\text { GLOVEBOX HC-21C FURNACE } \\
\text { CONTROL CONSOLE WIRING } \\
\text { DIAGRAM }\end{array}$ \\
\hline H-2-81310 SH. 5 & 7301 & $\begin{array}{l}\text { GLOVEBOX HC-2IC FURNACE \#2 } \\
\text { CONTROL CONSOLE WIRING } \\
\text { DIAGRAM }\end{array}$ \\
\hline H-2-81310 SH. 6 & 7301 & $\begin{array}{l}\text { GLOVEBOX HC-21C FURNACE } \\
\text { CONTROL PANEL, MISCELLANEOUS }\end{array}$ \\
\hline H-2-140584 SH.1 & $4700 / 8518$ & $\begin{array}{l}\text { SLUDGE STABILIZATION ROOMS } \\
\text { 230A/230B ARRANGEMENT }\end{array}$ \\
\hline H-2-140584 SH.2 & $4700 / 8518$ & $\begin{array}{l}\text { SLUDGE STABILIZATION ROOMS } \\
\text { 230A/230B PLAN }\end{array}$ \\
\hline H-2-140584 SH.3 & $4700 / 8518$ & $\begin{array}{l}\text { SLUDGE STABILIZATION ROOMS } \\
\text { 230A/230B MEZZANINE PLAN }\end{array}$ \\
\hline H-2-140584 SH.4 & $4700 / 8518$ & SLUDGE STABILIZATION ROOMS \\
\hline
\end{tabular}


HNF-SD-CP-SDD-017

Rev. 3

\begin{tabular}{|c|c|c|}
\hline \multicolumn{3}{|c|}{$\begin{array}{l}\text { THERMAL STABILIZATION IN GLOVEBOXES HC-21C, HC-18M, AND } \\
\text { HC-21A }\end{array}$} \\
\hline $\begin{array}{l}\text { Drawing } \\
\text { Number }\end{array}$ & Index No. & $\because \because$ \\
\hline & & 230A/230B SECTION \& DETAILS \\
\hline H-2-140585 SH.1 & $4700 / 8518$ & $\begin{array}{l}\text { HC-21C \& HC-21A SLUDGE } \\
\text { STABILIZATION GLOVEBOX } \\
\text { ARRANGEMENT }\end{array}$ \\
\hline H-2-140585 SH.2 & $4700 / 8518$ & $\begin{array}{l}\text { HC-21C \& HC-21 A SLUDGE } \\
\text { STABILIZATION GLOVEBOX } \\
\text { ARRANGEMENT }\end{array}$ \\
\hline $\mathrm{H}-2-140585 \mathrm{SH} .3$ & $4700 / 8518$ & $\begin{array}{l}\text { HC-21C \& HC-21A SLUDGE } \\
\text { STABILIZATION GLOVEBOX } \\
\text { ARRANGEMENT }\end{array}$ \\
\hline $\mathrm{H}-2-140588$ & 3902 & $\begin{array}{l}\text { SLUDGE STABILIZATION MUFFLE } \\
\text { FURNACE TOOLS }\end{array}$ \\
\hline H-2-815184 SH.1 & 7004 & SLUDGE STABILIZATION P\&ID \\
\hline H-2-815184 SH.2 & 7004 & $\begin{array}{l}\text { GLOVEBOX HC-21C SLUDGE } \\
\text { STABILIZATION P\&ID }\end{array}$ \\
\hline H-2-815184 SH.3 & 7004 & $\begin{array}{l}\text { GLOVEBOX HC-21A SLUDGE } \\
\text { STABILIZATION P\&ID }\end{array}$ \\
\hline
\end{tabular}


HNF-SD-CP-SDD-017

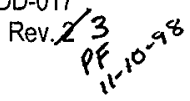

\section{APPENDIX B}

\section{MASTER COMPONENT INDEX LIST PFP THERMAL STABILIZATION SYSTEM}

\begin{tabular}{|c|c|c|c|c|c|c|}
\hline SYS & 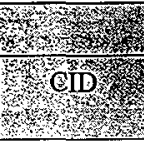 & 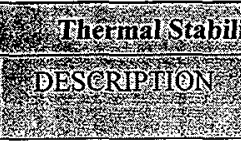 & 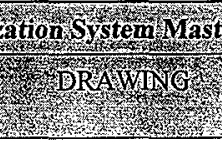 & 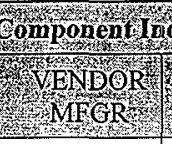 & dex & $\begin{array}{l}\text { CVI } \\
\mathrm{NO}\end{array}$ \\
\hline $73 \mathrm{~T}$ & CV-21C-1 & $\begin{array}{l}\text { CHECK VALVE } \\
\text { ON CO }{ }_{2} \text { INLET TO } \\
\text { FURNACE } 1\end{array}$ & $\begin{array}{l}\text { H-2-815184 SH. } 2 \\
\text { H-2-140584 }\end{array}$ & NUPRO & $\begin{array}{l}\text { MODEL\# SS- } \\
\text { CHS8-1 }\end{array}$ & $\begin{array}{l}22592 \\
\text { SUPP } \\
11\end{array}$ \\
\hline $73 T$ & CV-21C-2 & $\begin{array}{l}\text { CHECK VALVE } \\
\text { ON } \mathrm{CO}_{2} \text { INLET TO } \\
\text { FURNACE } 2\end{array}$ & $\begin{array}{l}\text { H-2-815184 SH. } 2 \\
\text { H-2-140584 }\end{array}$ & NUPRO & $\begin{array}{l}\text { MODEL\# SS- } \\
\text { CHS8-1 }\end{array}$ & $\begin{array}{l}22592 \\
\text { SUPP } \\
11\end{array}$ \\
\hline $73 \mathrm{~T}$ & DPI-21C-1 & $\begin{array}{l}\text { DIFFERENTIAL } \\
\text { PRESSURE } \\
\text { INDICATOR, OFF- } \\
\text { GAS FILTER } 1\end{array}$ & $\begin{array}{l}\mathrm{H}-2-815184 \text { SH. } 2 \\
\mathrm{H}-2-140585\end{array}$ & DWYER & MODEL\# 4215 & $\begin{array}{l}22592 \\
\text { SUPP } \\
12\end{array}$ \\
\hline $73 \mathrm{~T}$ & DPI-21C-2 & $\begin{array}{l}\text { DIFFERENTIAL } \\
\text { PRESSURE } \\
\text { INDICATOR, OFF- } \\
\text { GAS FILTER } 2\end{array}$ & $\begin{array}{l}\text { H-2-815184 SH. } 2 \\
\text { H-2-140585 }\end{array}$ & DWYER & MODEL\# 4215 & $\begin{array}{l}22592 \\
\text { SUPP } \\
12\end{array}$ \\
\hline $73 \mathrm{~T}$ & $\begin{array}{l}\text { EIC-21C- } \\
A\end{array}$ & CONTACTOR & $\begin{array}{l}\text { H-2-815184 SH. } 2 \\
\text { H-2-81310 }\end{array}$ & $\begin{array}{l}\text { EUROTHER } \\
\mathrm{M}\end{array}$ & MODEL\# 831 & $\begin{array}{l}22592 \\
\text { SUPP } \\
2\end{array}$ \\
\hline $73 \mathrm{~T}$ & EIC-21C-B & CONTACTOR & $\begin{array}{l}\text { H-2-815184 SH. } 2 \\
\text { H-2-81310 }\end{array}$ & $\begin{array}{l}\text { EUROTHER } \\
\mathrm{M}\end{array}$ & MODEL\# 831 & $\begin{array}{l}22592 \\
\text { SUPP } \\
2\end{array}$ \\
\hline $73 \mathrm{~T}$ & F-21C-1 & $\begin{array}{l}\text { OFF-GAS FILTER, } \\
\text { FURNACE } 1\end{array}$ & $\begin{array}{l}\text { H-2-815184 SH. } 2 \\
\text { H-2-140586 }\end{array}$ & $\begin{array}{l}\text { PALL } \\
\text { ADVANCED } \\
\text { SEPARATIO } \\
\text { NS } \\
\text { SYSTEMS }\end{array}$ & $\begin{array}{l}\text { MODEL\# C-23-40- } \\
\text { DCSC }\end{array}$ & $\begin{array}{l}22592 \\
\text { SUPP } \\
13\end{array}$ \\
\hline
\end{tabular}




\begin{tabular}{|c|c|c|c|c|c|c|}
\hline 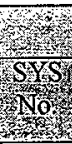 & 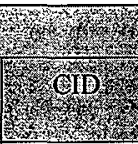 & 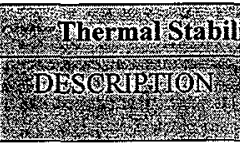 & 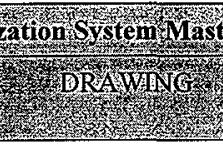 & 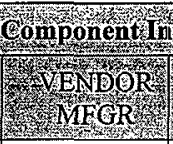 & dexk & $\mathrm{NO}$ \\
\hline $73 \mathrm{~T}$ & F-21C-2 & $\begin{array}{l}\text { OFF-GAS FILTER, } \\
\text { FURNACE } 2\end{array}$ & $\begin{array}{l}\text { H-2-815184 SH. } 2 \\
\text { H-2-140586 }\end{array}$ & $\begin{array}{l}\text { PALL } \\
\text { ADVANCED } \\
\text { SEPARATIO } \\
\text { NS } \\
\text { SYSTEMS }\end{array}$ & $\begin{array}{l}\text { MODEL\# C-23-40- } \\
\text { DCSC }\end{array}$ & $\begin{array}{l}22592 \\
\text { SUPP } \\
13\end{array}$ \\
\hline $73 \mathrm{~T}$ & FI-21C-1 & $\begin{array}{l}\text { FLOW } \\
\text { NNDICATOR, OFF- } \\
\text { GAS AFTER HX-1 }\end{array}$ & $\begin{array}{l}\text { H-2-815184 SH. } 2 \\
\text { H-2-140584 }\end{array}$ & DWYER & $\begin{array}{l}\text { MODEL\# RMC- } \\
\text { 103, 20-200 SCFH, } \\
0 " \text { FNPT PORTS }\end{array}$ & $\begin{array}{l}22592 \\
\text { SUPP } \\
12\end{array}$ \\
\hline $73 \mathrm{~T}$ & FI-21C-2 & $\begin{array}{l}\text { FLOW } \\
\text { INDICATOR, OFF- } \\
\text { GAS AFTER HX-2 }\end{array}$ & $\begin{array}{l}\text { H-2-815184 SH. } 2 \\
\text { H-2-140584 }\end{array}$ & DWYER & $\begin{array}{l}\text { MODEL\# RMC- } \\
\text { 103, 20-200 SCFH, } \\
\text { 0" FNPT PORTS }\end{array}$ & $\begin{array}{l}22592 \\
\text { SUPP } \\
12\end{array}$ \\
\hline $73 \mathrm{~T}$ & FI-21C-3 & $\begin{array}{l}\text { FLOW } \\
\text { NNDICATOR, } \mathrm{CO}_{2} \\
\text { TO FURNACE } 1\end{array}$ & $\begin{array}{l}\text { H-2-815184 SH. } 2 \\
\text { H-2-140584 }\end{array}$ & DWYER & $\begin{array}{l}\text { MODEL\# RMB- } \\
52-S S V, 5-50 \\
\text { SCFH, 0" FNPT } \\
\text { PORTS }\end{array}$ & $\begin{array}{l}22592 \\
\text { SUPP } \\
12\end{array}$ \\
\hline $73 \mathrm{~T}$ & FI-21C-4 & $\begin{array}{l}\text { FLOW } \\
\text { INDICATOR, } \mathrm{CO}_{2} \\
\text { TO FURNACE } 2\end{array}$ & $\begin{array}{l}\text { H-2-815184 SH. } 2 \\
\text { H-2-140584 }\end{array}$ & DWYER & $\begin{array}{l}\text { MODEL\# RMB- } \\
52-\mathrm{SSV}, 5-50 \\
\text { SCFH, 0" FNPT } \\
\text { PORTS }\end{array}$ & $\begin{array}{l}22592 \\
\text { SUPP } \\
12\end{array}$ \\
\hline $73 \mathrm{~T}$ & $\begin{array}{l}\text { FUR-21C- } \\
1\end{array}$ & $\begin{array}{l}\text { MUFFLE } \\
\text { FURNACE } 1\end{array}$ & $\begin{array}{l}\text { H-2-815184 SH. } 2 \\
\text { H-2-140585 }\end{array}$ & $\begin{array}{l}\text { THERMOLY } \\
\text { NE }\end{array}$ & MODEL\# FA1630 & $\begin{array}{l}22592 \\
\text { SUPP } \\
4\end{array}$ \\
\hline $73 \mathrm{~T}$ & $\begin{array}{l}\text { FUR-21C- } \\
2\end{array}$ & $\begin{array}{l}\text { MUFFLE } \\
\text { FURNACE } 2\end{array}$ & $\begin{array}{l}\text { H-2-815184 SH. } 2 \\
\text { H-2-140585 }\end{array}$ & $\begin{array}{l}\text { THERMOLY } \\
\text { NE }\end{array}$ & MODEL\# FA1630 & $\begin{array}{l}22592 \\
\text { SUPP } \\
4\end{array}$ \\
\hline $73 \mathrm{~T}$ & HS-21C-A & $\begin{array}{l}\text { HAND SWITCH, } \\
\text { START FURNACE } \\
1\end{array}$ & $\begin{array}{l}\text { H-2-815184 SH. } 2 \\
\text { H-2-81310 }\end{array}$ & $\begin{array}{l}\text { GENERAL } \\
\text { ELECTRIC }\end{array}$ & $\begin{array}{l}\text { MODEL\# } \\
\text { CR104PBT11G1S2 } \\
\text {, } 120 \text { VAC, } \\
\text { GREEN }\end{array}$ & 22592 \\
\hline $73 \mathrm{~T}$ & HS-21C-B & $\begin{array}{l}\text { HAND SWITCH, } \\
\text { STOP FURNACE } 1\end{array}$ & $\begin{array}{l}\text { H-2-815184 SH. } 2 \\
\text { H-2-81310 }\end{array}$ & $\begin{array}{l}\text { GENERAL } \\
\text { ELECTRIC }\end{array}$ & $\begin{array}{l}\text { MODEL\# } \\
\text { CR104PBT11R1S2 }\end{array}$ & 22592 \\
\hline
\end{tabular}




\begin{tabular}{|c|c|c|c|c|c|c|}
\hline & & & & & , 120 VAC, RED & \\
\hline $73 \mathrm{~T}$ & HS-21C-C & $\begin{array}{l}\text { HAND SWITCH, } \\
\text { START FURNACE } \\
2\end{array}$ & $\begin{array}{l}\text { H-2-815184 SH. } 2 \\
\text { H-2-81310 }\end{array}$ & $\begin{array}{l}\text { GENERAL } \\
\text { ELECTRIC }\end{array}$ & $\begin{array}{l}\text { MODEL\# } \\
\text { CR104PBT11G1S2 } \\
\text {, } 120 \mathrm{VAC}, \\
\text { GREEN }\end{array}$ & 22592 \\
\hline $73 \mathrm{~T}$ & HS-21C-D & $\begin{array}{l}\text { HAND SWITCH, } \\
\text { STOP FURNACE } 2\end{array}$ & $\begin{array}{l}\text { H-2-815184 SH. } 2 \\
\text { H-2-81310 }\end{array}$ & $\begin{array}{l}\text { GENERAL } \\
\text { ELECTRIC }\end{array}$ & $\begin{array}{l}\text { MODEL\# } \\
\text { CR104PBT11R1S2 } \\
\text {, 120 VAC, RED }\end{array}$ & 22592 \\
\hline $73 \mathrm{~T}$ & HS-21C-E & $\begin{array}{l}\text { HAND SWITCH, } \\
\text { FURNACE } \\
\text { EMERGENCY } \\
\text { STOP }\end{array}$ & $\begin{array}{l}\text { H-2-815184 SH. } 2 \\
\text { H-2-81310 }\end{array}$ & $\begin{array}{l}\text { ALLEN } \\
\text { BRADLEY }\end{array}$ & $\begin{array}{l}\text { PART\# 800T- } \\
\text { FXP16RA5 }\end{array}$ & $\begin{array}{l}22592 \\
\text { SUPP } \\
6\end{array}$ \\
\hline $73 \mathrm{~T}$ & $\begin{array}{l}\text { HS-21C- } \\
\text { HA }\end{array}$ & $\begin{array}{l}\text { HAND SWITCH, } \\
\text { HALON RELEASE } \\
\text { HOLD BUTTON }\end{array}$ & $\begin{array}{l}\mathrm{H}-2-815184 \text { SH. } 2 \\
\text { H-2-140584 }\end{array}$ & $\begin{array}{l}\text { GENERAL } \\
\text { ELECTRIC }\end{array}$ & $\begin{array}{l}\text { PART\# CN101J- } \\
250 F \\
\text { RED PUSH } \\
\text { BUTTON, 600V, } \\
10 \text { A }\end{array}$ & 22592 \\
\hline $73 T$ & LS-21C-1 & $\begin{array}{l}\text { LIMIT SWITCH, } \\
\text { FURNACE } 1 \\
\text { DOOR }\end{array}$ & H-2-815184 SH. 2 & $\begin{array}{l}\text { THERMOLY } \\
\text { NE }\end{array}$ & $\begin{array}{l}\text { COMPONENT OF } \\
\text { FURNACE } 1\end{array}$ & $\begin{array}{l}22592 \\
\text { SUPP } \\
4\end{array}$ \\
\hline $73 \mathrm{~T}$ & LS-21C-2 & $\begin{array}{l}\text { LIMIT SWITCH, } \\
\text { FURNACE } 2 \\
\text { DOOR }\end{array}$ & H-2-815184 SH. 2 & $\begin{array}{l}\text { THERMOLY } \\
\text { NE }\end{array}$ & $\begin{array}{l}\text { COMPONENT OF } \\
\text { FURNACE } 2\end{array}$ & $\begin{array}{l}22592 \\
\text { SUPP } \\
4\end{array}$ \\
\hline $73 \mathrm{~T}$ & $\begin{array}{l}\text { PRV-21A- } \\
1\end{array}$ & $\begin{array}{l}\text { PRESSURE } \\
\text { REGULATING } \\
\text { VALVE, }\end{array}$ & $\begin{array}{l}\mathrm{H}-2-815184 \text { SH. } 3 \\
\mathrm{H}-2-140584\end{array}$ & CONCOA & $\begin{array}{l}\text { MODEL\# 0405- } \\
3001,0-100 \text { PSI, } \\
\text { 1/4" FNPT PORTS }\end{array}$ & $\begin{array}{l}22592 \\
\text { SUPP } \\
11\end{array}$ \\
\hline $73 \mathrm{~T}$ & $\begin{array}{l}\text { PRV-21A- } \\
2\end{array}$ & $\begin{array}{l}\text { PRESSURE } \\
\text { REGULATING } \\
\text { VALVE, }\end{array}$ & $\begin{array}{l}\text { H-2-815184 SH. } 3 \\
\text { H-2-140584 }\end{array}$ & CONCOA & $\begin{array}{l}\text { MODEL\# 0405- } \\
\text { 3001, 0-100 PSI, } \\
\text { 1/4" FNPT PORTS }\end{array}$ & $\begin{array}{l}22592 \\
\text { SUPP } \\
11\end{array}$ \\
\hline $73 \mathrm{~T}$ & $\begin{array}{l}\text { PRV-21C- } \\
1\end{array}$ & $\begin{array}{l}\text { PRESSURE } \\
\text { REGULATING }\end{array}$ & $\begin{array}{l}\text { H-2-815184 SH. } 2 \\
\text { H-2-140584 }\end{array}$ & $\begin{array}{l}\text { BYRNE } \\
\text { SPECIALTY }\end{array}$ & $\begin{array}{l}\text { COMPONENT OF } \\
\mathrm{CO}_{2} \text { MANIFOLD, }\end{array}$ & $\begin{array}{l}22592 \\
\text { SUPP }\end{array}$ \\
\hline
\end{tabular}


HNF-SD-CP-SDD-017

Rev. $2{ }_{11} 3.98$

\begin{tabular}{|c|c|c|c|c|c|c|}
\hline Nows & 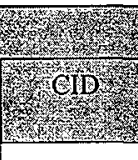 & 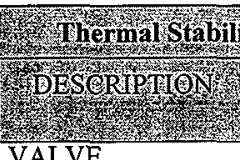 & 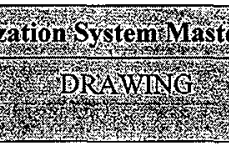 & 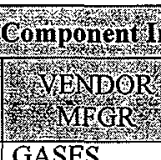 & WOMPNENI & 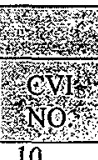 \\
\hline & & VALVE, & & GASES & MODEL\# LC-4-2 & 10 \\
\hline $73 \mathrm{~T}$ & $\begin{array}{l}\text { TAS-21C- } \\
\text { A }\end{array}$ & $\begin{array}{l}\text { TEMPERATURE } \\
\text { ALARM SWITCH, }\end{array}$ & $\begin{array}{l}\text { H-2-815184 SH. } 2 \\
\text { H-2-81310 }\end{array}$ & $\begin{array}{l}\text { EUROTHER } \\
\mathrm{M}\end{array}$ & $\begin{array}{l}\text { MODEL\# 93, } \\
\text { TEMP ALARM, } \\
\text { T/C INPUT, } \\
\text { MANUAL RESET }\end{array}$ & $\begin{array}{l}22592 \\
\text { SUPP } \\
5\end{array}$ \\
\hline $73 \mathrm{~T}$ & $\begin{array}{l}\text { TAS-21C- } \\
\text { B }\end{array}$ & $\begin{array}{l}\text { TEMPERATURE } \\
\text { ALARM SWITCH, }\end{array}$ & $\begin{array}{l}\text { H-2-815184 SH. } 2 \\
\text { H-2-81310 }\end{array}$ & $\begin{array}{l}\text { EUROTHER } \\
\mathrm{M}\end{array}$ & $\begin{array}{l}\text { MODEL\# } 93, \\
\text { TEMP ALARM, } \\
\text { T/C INPUT, } \\
\text { MANUAL RESET }\end{array}$ & $\begin{array}{l}22592 \\
\text { SUPP } \\
5\end{array}$ \\
\hline $73 \mathrm{~T}$ & $\begin{array}{l}\text { TAS-21C- } \\
\text { C }\end{array}$ & $\begin{array}{l}\text { TEMPERATURE } \\
\text { HIGH SELECT } \\
\text { ALARM SWITCH, } \\
\text { HC-21C } \\
\text { GLOVEBOX }\end{array}$ & $\begin{array}{l}\text { H-2-815184 SH. } 2 \\
\text { H-2-81310 }\end{array}$ & OMEGA & $\begin{array}{l}\text { MODEL\# CN101J- } \\
250 F, 6- \\
\text { CHANNEL, T/C } \\
\text { INPUTS, } \\
\text { MANUAL RESET }\end{array}$ & $\begin{array}{l}22592 \\
\text { SUPP } \\
7\end{array}$ \\
\hline $73 \mathrm{~T}$ & $\mathrm{TE}-21 \mathrm{C}-1$ & $\begin{array}{l}\text { THERMOCOUPLE } \\
\text {, }\end{array}$ & $\begin{array}{l}\text { H-2-815184 SH. } 2 \\
\text { ECN\# } 605466\end{array}$ & OMEGA & MODEL\# 4JX20PP & 22592 \\
\hline $73 \mathrm{~T}$ & TE-21C-2 & $\begin{array}{l}\text { THERMOCOUPLE } \\
\text {, }\end{array}$ & $\begin{array}{l}\text { H-2-815184 SH. } 2 \\
\text { ECN\# } 605466\end{array}$ & OMEGA & $\begin{array}{c}\text { MODEL\# 4JX20PP } \\
\cdot\end{array}$ & 22592 \\
\hline $73 \mathrm{~T}$ & TE-21C-3 & THERMOCOUPLE & $\begin{array}{l}\text { H-2-815184 SH. } 2 \\
\text { ECN\# } 605466\end{array}$ & OMEGA & MODEL\# 4JX20PP & 22592 \\
\hline $73 \mathrm{~T}$ & TE-21C-4 & $\begin{array}{l}\text { THERMOCOUPLE } \\
\end{array}$ & $\begin{array}{l}\text { H-2-815184 SH. } 2 \\
\text { ECN\# } 605466\end{array}$ & OMEGA & $\begin{array}{l}\text { MODEL\# } \\
\text { 4KX20PP }\end{array}$ & 22592 \\
\hline $73 \mathrm{~T}$ & TE-21C-5 & THERMOCOUPLE & $\begin{array}{l}\text { H-2-815184 SH. } 2 \\
\text { ECN\# } 605466\end{array}$ & OMEGA & $\begin{array}{l}\text { MODEL\# } \\
4 \mathrm{KX} 20 \mathrm{PP}\end{array}$ & 22592 \\
\hline $73 \mathrm{~T}$ & TE-21C-6 & $\begin{array}{l}\text { THERMOCOUPLE } \\
\end{array}$ & $\begin{array}{l}\text { H-2-815184 SH. } 2 \\
\text { ECN\# } 605466\end{array}$ & OMEGA & $\begin{array}{l}\text { MODEL\# } \\
4 \mathrm{KX} 20 \mathrm{PP}\end{array}$ & 22592 \\
\hline $73 \mathrm{~T}$ & TE-21C-7 & THERMOCOUPLE & $\begin{array}{l}\text { H-2-815184 SH. } 2 \\
\text { ECN\# } 605466\end{array}$ & OMEGA & $\begin{array}{l}\text { MODEL\# } \\
4 \mathrm{KX} 20 \mathrm{PP}\end{array}$ & 22592 \\
\hline $73 \mathrm{~T}$ & TE-21A-1 & $\begin{array}{l}\text { RTD IN HC-21A } \\
\text { GLOVEBOX }\end{array}$ & H-2-140584 SH 4 & OMEGA & $\begin{array}{l}\text { MODEL \# PR-13- } \\
2-100-3 / 16-6-E\end{array}$ & 22592 \\
\hline
\end{tabular}




\begin{tabular}{|c|c|c|c|c|c|c|}
\hline $73 \mathrm{~T}$ & TI-21A-1 & $\begin{array}{l}\text { TEMPERATURE } \\
\text { INDICATOR AND } \\
\text { ALARM FOR HC- } \\
\text { 21A GLOVEBOX }\end{array}$ & H-2-140584 SH 4 & OMEGA & $\begin{array}{l}\text { MODEL \# DP461- } \\
\text { RTD }\end{array}$ & 22592 \\
\hline $73 \mathrm{~T}$ & $\begin{array}{l}\text { TIC-21C- } \\
\text { A }\end{array}$ & $\begin{array}{l}\text { TEMPERATURE } \\
\text { INDICATOR } \\
\text { CONTROLLER, } \\
\text { FURNACE } 1\end{array}$ & $\begin{array}{l}\text { H-2-815184 SH. } 2 \\
\text { H-2-81310 }\end{array}$ & $\begin{array}{l}\text { EUROTHER } \\
\text { M }\end{array}$ & MODEL\# 818P15 & $\begin{array}{l}22592 \\
\text { SUPP } \\
1\end{array}$ \\
\hline $73 \mathrm{~T}$ & TIC-21C-B & $\begin{array}{l}\text { TEMPERATURE } \\
\text { INDICATOR } \\
\text { CONTROLLER, } \\
\text { FURNACE } 2\end{array}$ & $\begin{array}{l}\text { H-2-815184 SH. } 2 \\
\text { H-2-81310 }\end{array}$ & $\begin{array}{l}\text { EUROTHER } \\
\text { M }\end{array}$ & MODEL\# 818P15 & $\begin{array}{l}22592 \\
\text { SUPP } \\
1\end{array}$ \\
\hline $73 \mathrm{~T}$ & TR-21C & $\begin{array}{l}\text { TEMPERATURE } \\
\text { RECORDER }\end{array}$ & $\begin{array}{l}\text { H-2-815184 SH. } 2 \\
\text { H-2-140584 }\end{array}$ & TIGRAPH & $\begin{array}{l}\text { MODEL\# 200, 2- } \\
\text { CHANNEL }\end{array}$ & $\begin{array}{l}22592 \\
\text { SUPP } \\
8\end{array}$ \\
\hline $73 \mathrm{~T}$ & $\mathrm{~V}-21 \mathrm{~A}-1$ & $\begin{array}{l}\text { ARGON } \\
\text { ISOLATION } \\
\text { VALVE TO ROOM } \\
230 B\end{array}$ & $\begin{array}{l}\text { H-2-815184 SH. } 3 \\
\text { H-2-16475 }\end{array}$ & EXISTING & & \\
\hline $73 \mathrm{~T}$ & $\mathrm{~V}-21 \mathrm{~A}-2$ & $\begin{array}{l}\text { GLOBEVALVE } \\
\text { FOR ARGON } \\
\text { ISOLATIONTO } \\
\text { HOSE }\end{array}$ & $\begin{array}{l}\text { H-2-815184 SH. } 2 \\
\text { H-2-140584 }\end{array}$ & WALWORT & $\begin{array}{l}\text { MODEL } \# 3095 \text {, } \\
1 / 2 ", \text { CL150 }\end{array}$ & $\begin{array}{l}22592 \\
\text { SUPP } \\
12\end{array}$ \\
\hline $73 \mathrm{~T}$ & $V-21 A-10$ & $\begin{array}{l}\text { ARGON } \\
\text { ISOLATION } \\
\text { GLOBE VALVE }\end{array}$ & H-2-16475 & & & $\begin{array}{l}22592 \\
\text { SUPP }\end{array}$ \\
\hline $73 \mathrm{~T}$ & $\mathrm{~V}-21 \mathrm{~A}-11$ & $\begin{array}{l}\text { BALL VALVE, } 2 \\
\text { WAY, } 1 / 2 " \\
\text { SWAGELOCK } \\
\text { ENDS }\end{array}$ & H-2-140584, SH 1 & WHITEY & MODEL \# SS45S8 & $\begin{array}{l}22592 \\
\text { SUPP }\end{array}$ \\
\hline $73 \mathrm{~T}$ & $V-21 \mathrm{C}-1$ & NEEDLE VALVE, & H-2-815184 SH. 2 & WHITEY & MODEL\# SS-IRS8- & 22592 \\
\hline
\end{tabular}




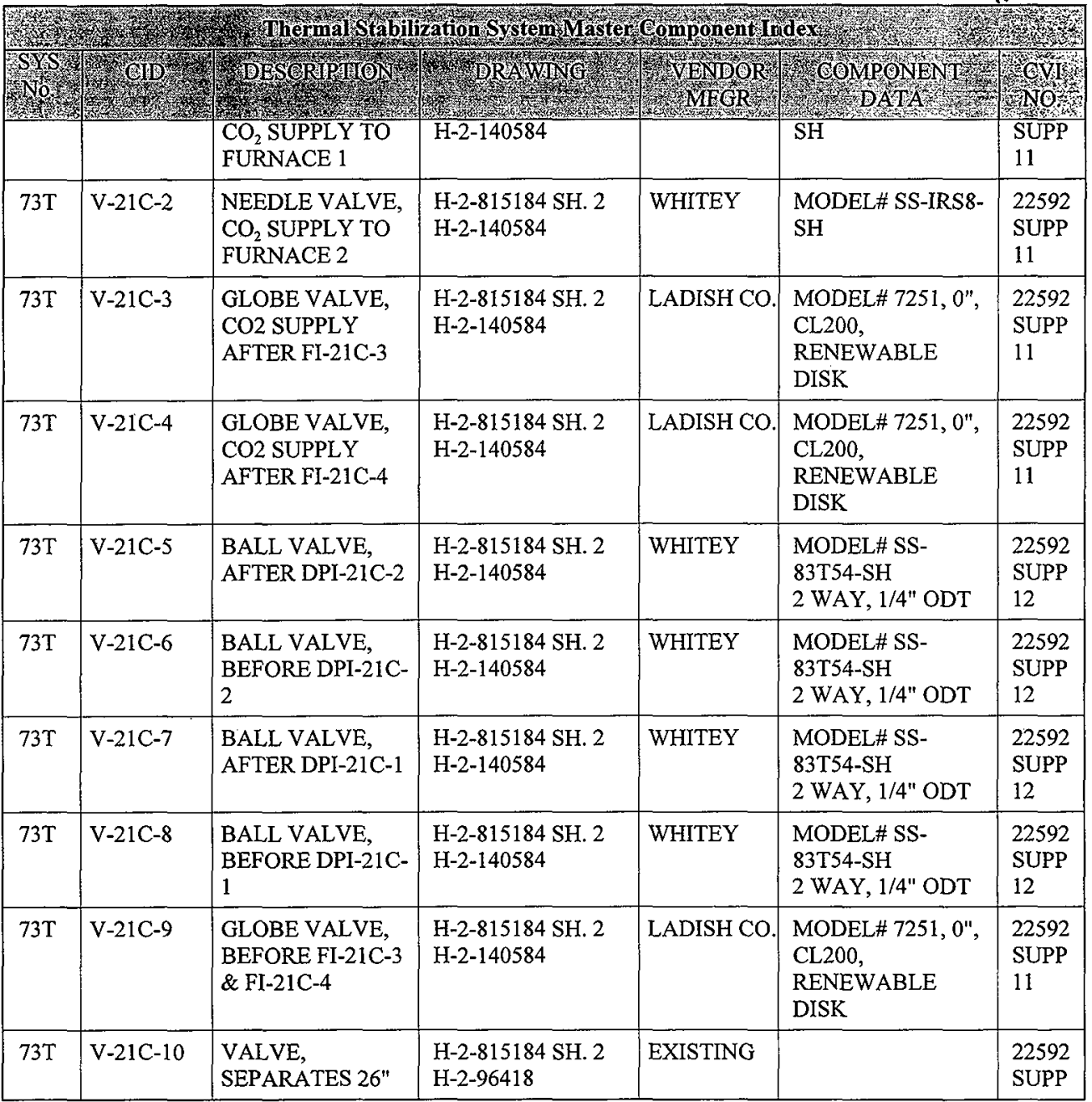


HNF-SD-CP-SDD-017

Rev.2 3 PF

$11-10-98$

\begin{tabular}{|c|c|c|c|c|c|c|}
\hline Sys & (3) & 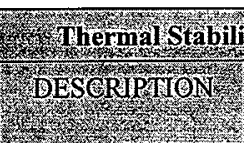 & 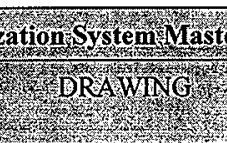 & 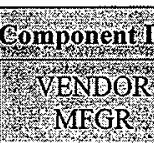 & 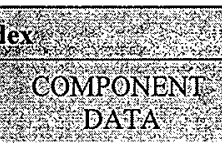 & Go \\
\hline & & $\begin{array}{l}\text { VACUUM } \\
\text { SYSTEM AND 73T }\end{array}$ & & & & 11 \\
\hline $73 \mathrm{~T}$ & $\mathrm{~V}-21 \mathrm{C}-11$ & $\begin{array}{l}\text { VALVE, 3-WAY } \\
\text { ISOLATES FI-21C- } \\
1\end{array}$ & $\begin{array}{l}\text { H-2-815184 SH. } 2 \\
\text { H-2-96418 }\end{array}$ & WHITEY & $\begin{array}{l}3 \text { WAY BALL, } \\
1 / 2 " \\
\text { SS-45S } 8\end{array}$ & $\begin{array}{l}22592 \\
\text { SUPP } \\
11\end{array}$ \\
\hline $73 \mathrm{~T}$ & $\mathrm{~V}-21 \mathrm{C}-12$ & $\begin{array}{l}\text { VALVE, 3-WAY } \\
\text { ISOLATES FI-21C- } \\
1\end{array}$ & $\begin{array}{l}\mathrm{H}-2-815184 \text { SH. } 2 \\
\mathrm{H}-2-96418\end{array}$ & WHITEY & $\begin{array}{l}3 \text { WAY BALL, } \\
1 / 2^{\prime \prime} \\
\text { SS-45S } 8\end{array}$ & $\begin{array}{l}22592 \\
\text { SUPP } \\
11\end{array}$ \\
\hline $73 \mathrm{~T}$ & $V-21 C-13$ & $\begin{array}{l}\text { VALVE, } \\
\text { ISOLATES PI-21C- } \\
1\end{array}$ & $\begin{array}{l}\text { H-2-815184 SH. } 2 \\
\text { H-2-96418 }\end{array}$ & WHITEY & $\begin{array}{l}2 \text { WAY BALL, } \\
1 / 4 " \text { NPT } \\
\text { SS-62TF4 }\end{array}$ & $\begin{array}{l}22592 \\
\text { SUPP } \\
11\end{array}$ \\
\hline $73 \mathrm{~T}$ & $V-21 C-14$ & $\begin{array}{l}\text { VALVE } \\
\text { ISOLATES PI-21C- } \\
2\end{array}$ & $\begin{array}{l}\text { H-2-815184 SH. } 2 \\
\text { H-2-96418 }\end{array}$ & WHITEY & $\begin{array}{l}2 \text { WAY BALL, } \\
1 / 4 " \text { NPT } \\
\text { SS-62TF4 }\end{array}$ & $\begin{array}{l}22592 \\
\text { SUPP } \\
11\end{array}$ \\
\hline $73 \mathrm{~T}$ & $V-21 C-15$ & $\begin{array}{l}\text { VALVE, 3-WAY } \\
\text { ISOLATES FI-21C- } \\
2\end{array}$ & $\begin{array}{l}\mathrm{H}-2-815184 \text { SH. } 2 \\
\mathrm{H}-2-96418\end{array}$ & WHITEY & $\begin{array}{l}3 \text { WAY BALL, } \\
1 / 2^{\prime \prime} \\
\text { SS-45S8 }\end{array}$ & $\begin{array}{l}22592 \\
\text { SUPP } \\
11\end{array}$ \\
\hline $73 \mathrm{~T}$ & $V-21 C-16$ & $\begin{array}{l}\text { VALVE, 3-WAY } \\
\text { ISOLATES FI-21C- } \\
2\end{array}$ & $\begin{array}{l}\text { H-2-815184 SH. } 2 \\
\text { H-2-96418 }\end{array}$ & WHITEY & $\begin{array}{l}3 \text { WAY BALL, } \\
1 / 2^{\prime \prime} \\
\text { SS- } 45 \text { S } 8\end{array}$ & $\begin{array}{l}22592 \\
\text { SUPP } \\
11\end{array}$ \\
\hline $73 \mathrm{~T}$ & DPI-21C-3 & $\begin{array}{l}\text { DPI ACROSS FO- } \\
21 \mathrm{C}-1\end{array}$ & $\begin{array}{l}\text { H-2-815184 SH. } 2 \\
\text { H-2-96418 }\end{array}$ & DWYER & $\begin{array}{l}\text { GAGE, 0-8"H2O, } \\
\text { 1/8" FNPT, \#2008 }\end{array}$ & $\begin{array}{l}22592 \\
\text { SUPP } \\
11\end{array}$ \\
\hline $73 \mathrm{~T}$ & DPI-21C-4 & $\begin{array}{l}\text { DPI ACROSS FO- } \\
21 \mathrm{C}-2\end{array}$ & $\begin{array}{l}\text { H-2-815184 SH. } 2 \\
\text { H-2-96418 }\end{array}$ & DWYER & $\begin{array}{l}\text { GAGE, } 0-8 " \mathrm{H} 2 \mathrm{O}, \\
1 / 8 \text { " FNPT, \#2008 }\end{array}$ & $\begin{array}{l}22592 \\
\text { SUPP } \\
11\end{array}$ \\
\hline $73 \mathrm{~T}$ & FO-21C-1 & $\begin{array}{l}\text { ORIFICE FOR OFF } \\
\text { GAS FOR FUR- } \\
21 \mathrm{C}-1\end{array}$ & $\begin{array}{l}\text { H-2-815184 SH. } 2 \\
\text { H-2-96418 }\end{array}$ & & & \\
\hline $73 \mathrm{~T}$ & FO-21C-2 & ORIFICE FOR OFF & H-2-815184 SH. 2 & & & \\
\hline
\end{tabular}




\begin{tabular}{|c|c|c|c|c|c|c|}
\hline \\
\hline \multicolumn{7}{|c|}{ 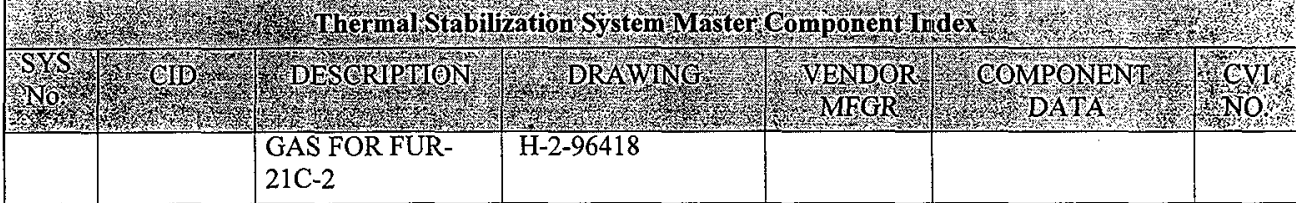 } \\
\hline $73 \mathrm{~T}$ & PI-21C-1 & $\begin{array}{l}\text { PRESS } \\
\text { INDICATOR FOR } \\
26^{\prime \prime} \text { VAC SUPPLY } \\
(230 A)\end{array}$ & $\begin{array}{l}\text { H-2-815184 SH. } 2 \\
\text { H-2-96418 }\end{array}$ & ASHCROFT & $\begin{array}{l}\text { GAGE, 0-30" HG } \\
\text { 3KA16978-017 }\end{array}$ & $\begin{array}{l}22592 \\
\text { SUPP } \\
11\end{array}$ \\
\hline $73 \mathrm{~T}$ & PI-21C-2 & $\begin{array}{l}\text { PRESS } \\
\text { INDICATOR FOR } \\
26^{\prime \prime} \text { VAC SUPPLY } \\
(263)\end{array}$ & $\begin{array}{l}\text { H-2-815184 SH. } 2 \\
\text { H-2-96418 }\end{array}$ & ASHCROFT & $\begin{array}{l}\text { GAGE, 0-30" HG } \\
\text { 3KA16978-017 }\end{array}$ & $\begin{array}{l}22592 \\
\text { SUPP } \\
11\end{array}$ \\
\hline
\end{tabular}


DISTRIBUTION SHEET

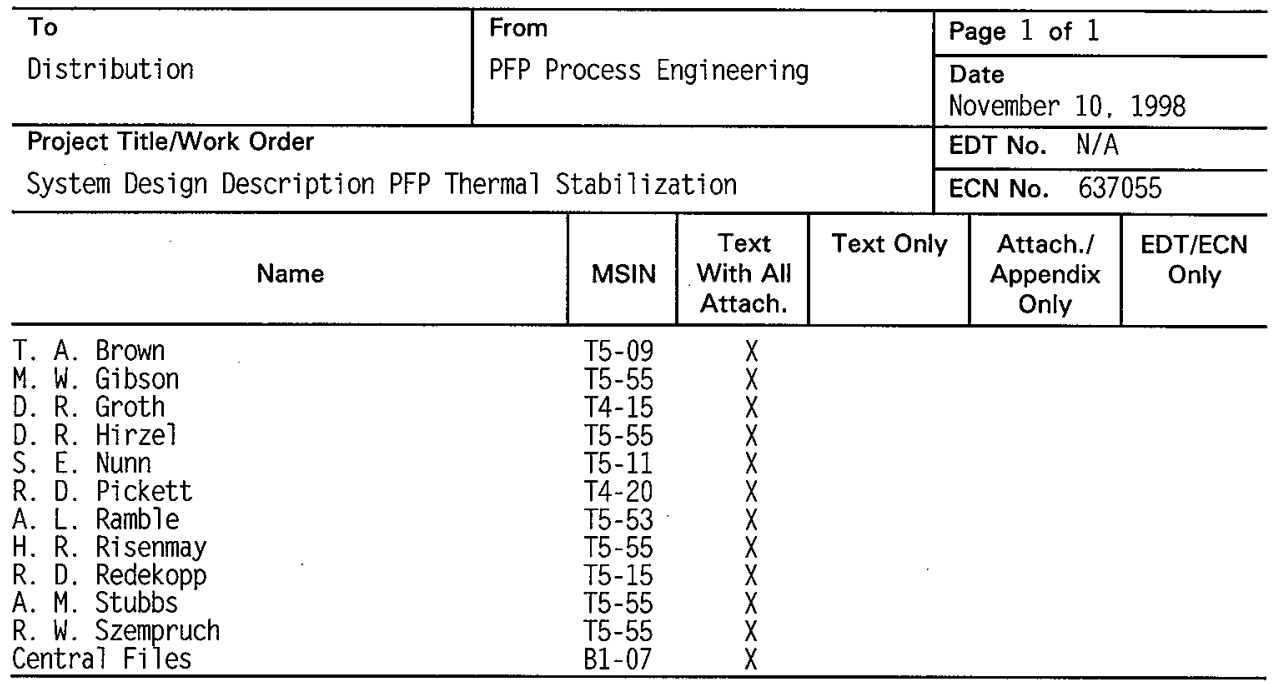

